\title{
Espécies arbóreas de Papilionoideae (Leguminosae) na região noroeste do estado de São Paulo, Brasil ${ }^{1}$
}

Tree species of Papilionoideae (Leguminosae) in northwest of São Paulo state, Brazil

\author{
Milena Ventrichi Martins ${ }^{1,2,4}$, Osmar Cavassan ${ }^{3}$, Ana Maria Goulart de Azevedo Tozzi ${ }^{2}$ \& Ingrid Koch ${ }^{2}$
}

\begin{abstract}
Resumo
Neste estudo foram coletados os indivíduos arbóreos e arbustivos da subfamília Papilionoideae na região noroeste do estado de São Paulo, Sudeste do Brasil. A área possui a vegetação mais fragmentada do Estado e é ainda pouco conhecida quanto à composição da flora. Foram registradas 19 espécies arbóreas de Papilionoideae reunidas em 11 gêneros e três tribos. As tribos mais representativas foram Sophoreae, com Bowdichia, Leptolobium, Myroxylon, Ormosia e Sweetia, e Dalbergieae com Andira, Centrolobium, Machaerium e Platypodium, enquanto Dipterygeae foi representada por Dipteryx e Pterodon. O gênero com maior número de espécies foi Machaerium, com oito, seguido por Leptolobium, com duas. Os demais gêneros foram representados por uma espécie cada. Os dados de distribuição das espécies apontam para uma flora regional composta por espécies com ampla distribuição no domínio Cerrado, do Brasil central, e espécies que ocorrem prioritariamente no domínio de Mata Atlântica, no Brasil oriental. Chaves para identificação, descrições e ilustrações dos táxons encontrados são apresentadas.
\end{abstract}

Palavras-chave: Fabaceae, Faboideae, Cerrado, Floresta Estacional Semidecidual, florística.

\begin{abstract}
In this study, we collected woody plants of Papilionoideae, Leguminosae, in the northwest region of São Paulo state, southeastern Brazil. The study area has one of the most fragmented vegetation within the context of the region, and it is still poorly known about the flora. Nineteen species were recorded in eleven genera and three tribes. The most representative tribes were Sophoreae, with the genus Bowdichia, Leptolobium, Myroxylon, Sweetia and Ormosia; tribe Dalbergieae, with Andira, Centrolobium, Machaerium and Platypodium, and tribe Dipterygeae represented by Dipteryx and Pterodon. Machaerium presented the highest number of species, with eight, followed by Leptolobium, with two species. The other genera were represented by one species each. The species distribution data showed that the regional flora consists of species with wide distribution in the Cerrado, in central Brazil, and species that occur primarily in the Atlantic forest in eastern Brazil. Keys, descriptions and illustrations of the taxa found are displayed.
\end{abstract}

Keywords: Fabaceae, Faboideae, Cerrado, Semideciduous Forest, floristic.

\section{Introdução}

Leguminosae Juss. (Fabaceae Lindl.) é a terceira maior família das angiospermas com cerca de 750 gêneros e 19.500 espécies (Lewis et al. 2005). Tradicionalmente está subdividida em três subfamílias: Caesalpinioideae, Mimosoideae e Papilionoideae (Faboideae), porém a circunscrição e o número das subfamílias, a serem reconhecidas para a família estão em discussão (LPWG 2013). Propostas de uma nova classificação sugerem a divisão da parafilética subfamília Caesalpinioideae em várias subfamílias (seis ou 10 a 15) e a manutenção das subfamílias Mimosoideae e Papilionoideae (LPWG 2013).

\footnotetext{
'Parte da dissertação de Mestrado apresentada pela primeira autora ao Programa de Pós-Graduação-Ciências Biológicas (Botânica), Universidade Estadual Paulista "Julio de Mesquita Filho", Campus de Botucatu, Inst. Biociências, Distrito Rubião Junior s/n, 18618-970 , Botucatu, SP, Brasil. Bolsista FAPESP (Processo 07/53885-9).

${ }^{2}$ Universidade Estadual de Campinas, Inst. Biologia, Depto. Biologia Vegetal, 13083-862, Campinas, SP, Brasil.

${ }^{3}$ Universidade Estadual Paulista "Julio de Mesquita Filho", Campus de Bauru, Depto. Ciências Biológicas, Av. Luis Edmundo Carrijo Coube, 1401, 17053-900, Bauru, SP, Brasil.

${ }^{4}$ Autor para correspondência: milory@gmail.com
} 
Análises filogenéticas e características morfológicas sustentam o monofiletismo de Papilionoideae (Doyle et al. 1997; Pennington et al. 2001; Wojciechowski et al. 2004; Cardoso et al. 2012), a qual é a maior das subfamílias de Leguminosae, com aproximadamente 13.800 espécies distribuídas em 483 gêneros e 28 tribos, de distribuição cosmopolita (Lewis et al. 2005). As espécies de Papilionoideae são caracterizadas pelas folhas pinadas, uni a multi-folioladas e pelas flores papilionáceas com simetria zigomorfa e prefloração imbricada vexilar, exceto nas espécies das tribos Sophoreae e Swartzieae que possuem flores geralmente actinomorfas (Lewis et al. 2005). No Brasil ocorrem cerca de 100 gêneros e 1100 espécies e, deste total, aproximadamente 67 gêneros e 348 espécies estão representados no estado de São Paulo (BFG 2015).

A região noroeste paulista é considerada uma das mais desmatadas e fragmentadas do estado de São Paulo, pelo histórico de degradação e exploração, fato agravado pelo pequeno número de unidades de conservação (Kronka et al. 2005; Necchi Júnior 2012). Este quadro somado ao conhecimento insuficiente sobre a diversidade resultou na indicação da região como "prioritária para o levantamento de fauna e flora no estado de São Paulo" por Metzger \& Rodrigues (2008) e no desenvolvimento de um projeto de pesquisa, que visou obter uma base para estudos de conservação da biodiversidade de fragmentos florestais remanescentes na região noroeste do estado de São Paulo (Necchi Júnior et al. 2012). Quanto à flora, o estudo resultou em uma síntese do conhecimento sobre a diversidade na região, com a caracterização florística de remanescentes de vegetação nativa (Taroda et al. 2012), mas, embora seja relevante a listagem de espécies, o trabalho não fornece chaves de identificação ou descrições que facilitem o pronto reconhecimento das mesmas. Nesta listagem a família Leguminosae foi representada por 71 das 468 espécies $(15,2 \%)$ e a subfamília Papilionoideae por 31 espécies (Taroda et al. 2012).

Neste contexto, o presente estudo objetivou, além de contribuir para o inventário das espécies arbóreas da subfamília Papilionoideae de Leguminosae representativas nas formações florestais da região noroeste do estado de São Paulo, fornecer subsídios para o reconhecimento das mesmas, por meio de chaves de identificação, descrições, ilustrações e comentários sobre a delimitação das espécies, e informações sobre sua a distribuição e períodos de floração e frutificação.

\section{Material e Métodos}

A região noroeste do estado de São Paulo localiza-se no planalto ocidental paulista (Troppmair 1975), com topografia suave e relevo ondulado, relativamente uniforme (Arid et al. 1970). Seus limites incluem integralmente as Unidades de Gerenciamento dos Recursos Hídricos (UGRHIs) do Turvo-Grande e São José dos Dourados e partes das UGHRIs do Baixo Pardo, Baixo Tietê e Tietê-Batalha (Necchi Júnior et al. 2012). Esta área compreende as regiões administrativas de São José do Rio Preto, Araçatuba, e parte das regiões administrativas de Bauru (porção norte) e Ribeirão Preto (porção oeste) (Fig.1; Necchi Júnior et al. 2012).

O clima da região é classificado como Tropical Quente e Úmido (Aw de Köppen), com precipitação total anual entre 1.100 e $1.250 \mathrm{~mm}$ ( $\pm 225 \mathrm{~mm}$ ), estação chuvosa entre outubro e março (cerca de $85 \%$ da precipitação total anual) e estação seca entre abril e setembro (cerca $15 \%$ da precipitação total anual) (Barcha \& Arid 1971). As temperaturas médias anuais são sempre maiores que $25^{\circ} \mathrm{C}$, com junho e julho correspondendo aos meses mais frios (média de cerca de $20^{\circ} \mathrm{C}$ ) e janeiro e fevereiro aos meses mais quentes (média de cerca de $30^{\circ} \mathrm{C}$ ) (Barcha $\&$ Arid 1971). A vegetação remanescente na região é caracterizada como predominantemente de Floresta Estacional Semidecidual, seguida por Cerrado e áreas de contato entre as duas fisionomias (Kronka et al. 2005).

$\mathrm{O}$ estudo foi desenvolvido em fragmentos nos municípios de Macaubal, Matão, Novo Horizonte, Planalto, Sales, Santo Antônio do Aracanguá, São João de Iracema, Turmalina, União Paulista e Votuporanga (Fig.1). As fisionomias predominantes nos fragmentos são Floresta Estacional Semidecidual e Cerrado, especificamente do tipo Cerradão (Veloso et al. 1991).

Amostras dos indivíduos arbustivos e arbóreos foram coletadas entre julho de 2007 e julho de 2008, percorrendo-se de forma assistemática o máximo de extensão de cada fragmento visitado. Todo o material coletado seguiu o procedimento de herborização de Fidalgo \& Bononi (1989) e posteriormente foi depositado nos herbários BOTU e SJRP. Além do material coletado, foram examinadas as exsicatas provenientes da região em estudo dos Herbários BOTU, ESA, IAC, SP, SJRP, SPF e UEC. 


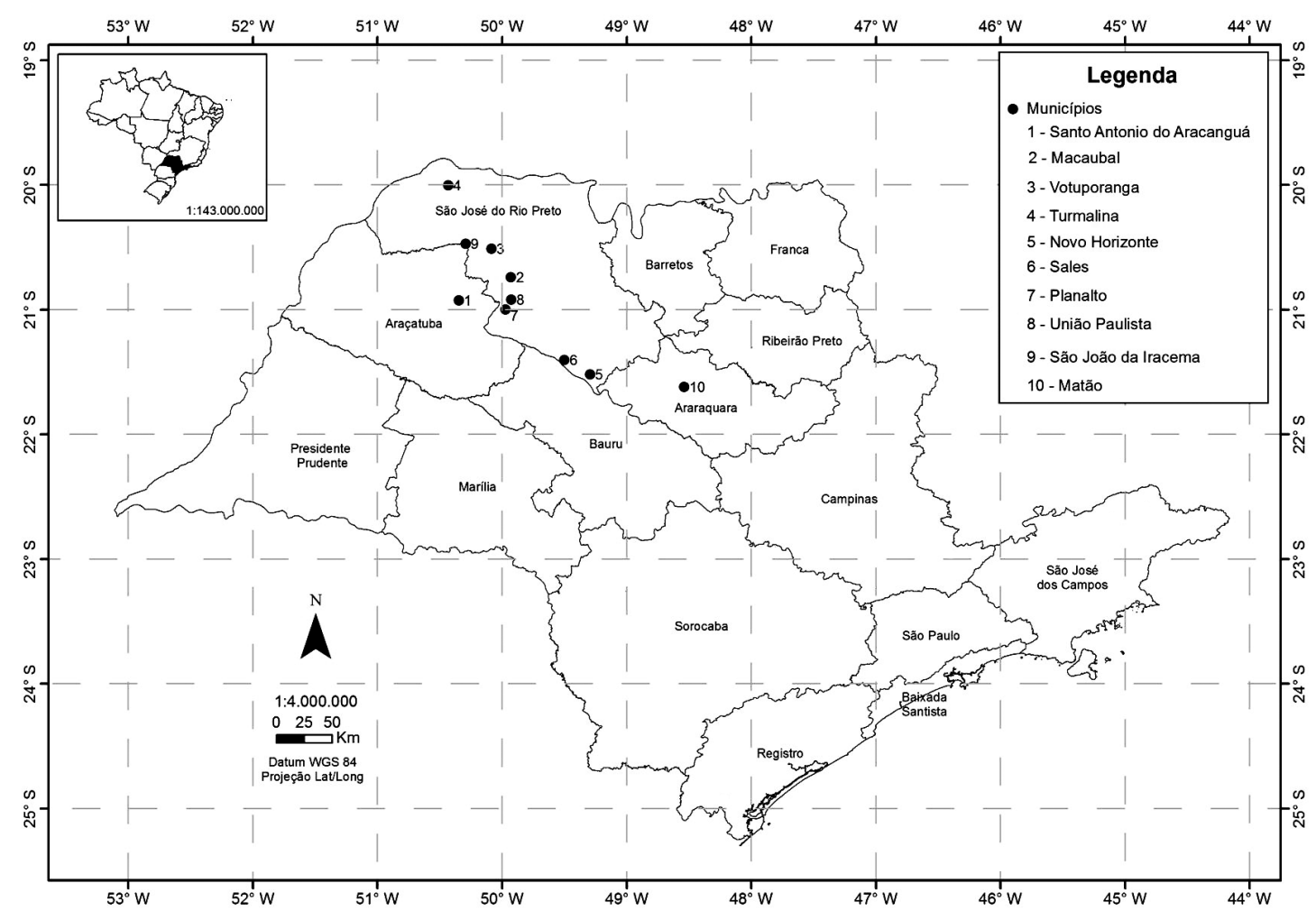

Figura 1 - Mapa de localização da região noroeste do estado de São Paulo com indicação das regiões administrativas e pontos onde foram realizadas as coletas, com indicação do município.

Figure 1 - Location map of the northwest region of São Paulo with administrative Region and points where the samples were taken with the municipalities.

A identificação das espécies foi realizada a partir do exame do material vegetativo e reprodutivo em estereomicroscópio e utilização de chaves de identificação e descrições constantes em bibliografia especializada, comparação com materiais identificados depositados nos herbários, imagens digitalizadas de espécimes "tipo" e auxílio de especialistas, quando necessário. Foi adotada a classificação de Lewis et al. (2005) para nomear as tribos. A nomenclatura morfológica adotada nas descrições foi baseada nos trabalhos de Radford et al. (1974), Rizzini (1977) e Polhill \& Raven (1981); para frutos utilizou-se Barroso et al. (1999). Para confirmar as grafias dos nomes dos táxons foram consultadas a bibliografia pertinente ao grupo e a base de dados da Lista de Espécies da Flora do Brasil (BFG 2015).

As diagnoses genéricas, elaboradas quando o gênero foi representado por mais de uma espécie, basearam-se na literatura pertinente ao grupo taxonômico, a qual foi indicada após a descrição. A amplitude morfológica considerada para a elaboração da chave para identificação e as descrições das espécies foi aquela observada no material coletado na região noroeste do estado de São Paulo. As ilustrações de características diagnósticas foram feitas sob câmara-clara acoplada a estereomicroscópio Zeiss, e para cinco espécies não ilustradas foram citadas iconografias da Flora Brasiliensis (Bentham 1862) e do artigo de Sartori \& Tozzi (1998). Os comentários taxonômicos foram baseados nas observações de campo, nas análises de exsicatas e também em literatura pertinente aos grupos taxonômicos. Os dados de floração e frutificação foram baseados no material coletado na região. Material adicional foi utilizado quando o material coletado na região não estava completo para a descrição de todas as estruturas morfológicas.

Para a análise das distribuições geográficas e ocorrência em domínios fitogeográficos das 
espécies encontradas na região noroeste foi elaborada uma tabela com informações gerais sobre a ocorrência de cada espécie, a partir dos dados da base Tropicos (2015), da Lista de Espécies da Flora do Brasil (BFG 2015), de literatura pertinente aos táxons (e.g. Sartori \& Tozzi 1998) e de estudos abordando fisionomias vegetacionais do estado de São Paulo (Durigan et al. 2004, 2012). Além disso, foram avaliados os registros de ocorrência de material depositado em coleções de herbário, obtidos a partir da rede speciesLink (2015). Os registros foram visualizados a partir do mapa global para cada espécie no speciesLink (2015), para se ter uma ideia mais detalhada sobre a sua distribuição e as informações foram comparadas com os dados disponíveis em literatura específica, sempre que possível, para minimizar a entrada de erros de identificação pertinentes aos dados de coleções.

A partir da análise foi possível verificar a existência de dois padrões principais de distribuição para as espécies, nomeados neste estudo como "tipo 1" e "tipo 2". No padrão "tipo 1" os registros foram mais concentrados no domínio Cerrado, no Brasil central, com maior densidade no planalto ocidental, no estado de São Paulo. No padrão "tipo 2" os registros foram predominantes no domínio Mata Atlântica, nas regiões Nordeste, Sudeste e Sul, e apresentaram, em geral, poucos registros no planalto ocidental paulista.

\section{Resultados e Discussão}

No noroeste paulista foram encontradas 19 espécies arbustivas e/ou arbóreas da subfamília Papilionoideae, distribuídas em 11 gêneros e três tribos. As tribos mais representativas em número de gêneros foram Sophoreae, com Bowdichia Kunth, Leptolobium Vogel, Myroxylon L.f., Ormosia Jacks. e Sweetia Spreng., e Dalbergieae, com Andira Lam., Centrolobium Mart., Machaerium Pers. e Platypodium Vogel, enquanto Dipterygeae foi representada por Dipteryx Schreb. e Pterodon Vogel. O gênero mais diverso foi Machaerium, com oito espécies, seguido por Leptolobium, com duas espécies. Os demais nove gêneros foram representados por uma única espécie cada.

As espécies inventariadas na região noroeste já haviam sido relacionadas para o estado de São Paulo (Wanderley et al. 2011) e são, em sua maioria, amplamente distribuídas no Brasil e nos países vizinhos, sendo apenas Centrolobium tomentosum Guillem. ex Benth. e Pterodon pubescens
(Benth.) Benth. restritas ao Brasil (Tab.1; BFG 2015). Sete espécies (Andira vermifuga (Mart.) Benth., Bowdichia virgilioides Kunth, Dipteryx alata Vogel, Leptolobium dasycarpum Vogel, Machaerium acutifolium Vogel, Platypodium elegans Vogel e Pterodon pubescens) ocorreram em fragmentos caracterizados como Cerradão e foram classificadas como padrão "tipo 1" de distribuição, com ocorrência prioritária no domínio Cerrado, no Brasil central, e maior densidade de registros no planalto ocidental paulista (speciesLink 2015). No Brasil estas sete espécies ocorrem prioritariamente no domínio Cerrado, mas também na Caatinga, Pantanal e/ou na Mata Atlântica, desde a região norte (principalmente no Maranhão) e nordeste até sudeste (São Paulo) ou sul (norte do Paraná) (BFG 2015; speciesLink 2015).

Outras seis espécies (Centrolobium tomentosum, Leptolobium elegans Vogel, Machaerium nyctitans (Vell.) Benth., M. stipitatum (DC.) Vogel, M. villosum Vogel e Ormosia arborea (Vell.) Harms ocorreram nos fragmentos de Floresta Estacional Semidecidual (Tab. 1). Exceto por M. stipitatum, amplamente coletado em todo o estado de São Paulo, estas espécies possuem poucos registros no planalto ocidental paulista (speciesLink 2015) e no Brasil são registradas predominantemente no domínio Mata Atlântica, nas regiões nordeste (Bahia), sudeste e sul (Paraná, Santa Catarina ou Rio Grande do Sul) (Lima et al. 2015; speciesLink 2015) (padrão tipo 2).

As demais seis espécies (Machaerium amplum Benth., M. brasiliense Vogel, $M$. hirtum (Vell.) Stellfeld, M. paraguariensis Hassl., Myroxylon peruiferum L.f. e Sweetia fruticosa Spreng. ocorreram tanto em Cerradão como em Floresta Estacional Semidecidual (Tab. 1), apesar de $M$. amplum e $M$. hirtum apresentarem padrão de distribuição similar ao tipo 1 e de $M$. brasiliense, M. paraguariense e Sweetia fruticosa apresentarem padrão de distribuição similar ao tipo 2 .

Apesar do estudo das Papilionoideae da região noroeste do estado de São Paulo abarcar um número limitado de espécies, os dados apontam para uma flora composta por elementos com ampla distribuição no domínio Cerrado do Brasil central, em conjunto com elementos do domínio Mata Atlântica, provenientes da porção oriental do Brasil, similar ao relatado por Vivo (1998) para os mamíferos do estado de São Paulo. É provável que este padrão se repita para outros grupos taxonômicos. 
Tabela 1 - Distribuição geográfica, domínios fitogeográficos no Brasil e tipo de vegetação no estado de São Paulo das Papilionoideae coletadas na região no noroeste paulista. Distribuição no Brasil: siglas designativas das Unidades da Federação. Domínio fitogeográfico: Am - Amazônia, Ca - Caatinga, Ce - Cerrado, Ma - Mata Atlântica, Pa - Pantanal. Tipos de vegetação (fitofisionomia): Cer-Cerrado lato sensu, Fod - Floresta Ombrófila Densa, Fes - Floresta Estacional Semidecidual. Referências: 1- Tropicos.org 2015, 2- BFG 2015, 3- Durigan et al. 2004, 4- Rodrigues \& Tozzi 2012, 5- Sartori \& Tozzi 1998.

Table 1 - Geographical distribution, phytogeographic domains in Brazil and type of vegetation in São Paulo of Papilionoideae collected in the region in northwestern São Paulo. Distribution in Brazil: designative acronyms of Federative Units. Phytogeographic domains: Am - Amazonia, Ca - Caatinga, Ce - Cerrado, Ma - Atlantic Forest, Pa - Pantanal. References: 1- Tropicos.org 2015, 2- BFG 2015, 3- Durigan et al. 2004, 4- Rodrigues \& Tozzi 2012, 5- Sartori \& Tozzi 1998.

\begin{tabular}{|c|c|c|c|c|c|}
\hline Espécie & $\begin{array}{l}\text { Distribuição } \\
\text { mundial }\end{array}$ & Distribuição no Brasil & $\begin{array}{l}\text { Dom.fitogeog. } \\
\text { Brasil }\end{array}$ & $\begin{array}{l}\text { Tipo } \\
\text { vegetação SP }\end{array}$ & Referências \\
\hline Andira vermifuga & Bolívia, Brasil & $\begin{array}{l}\text { AC, AM, TO, BA, CE, MA, } \\
\text { PI, DF, GO, MS, MT, MG, SP }\end{array}$ & $\begin{array}{l}\mathrm{Am}, \mathrm{Ca}, \mathrm{Ce}, \\
\mathrm{Ma}\end{array}$ & $\mathrm{Ce}$ & $1,2,3$ \\
\hline $\begin{array}{l}\text { Bowdichia } \\
\text { virgilioides }\end{array}$ & $\begin{array}{l}\text { Bolívia, Colômbia, } \\
\text { Guiana, Suriname, } \\
\text { Venezuela, Brasil }\end{array}$ & $\begin{array}{l}\text { AM, AP, PA, RO, RR, TO, } \\
\text { AL, BA, CE, MA, PA, PE, PI, } \\
\text { RN, SE, DF, GO, MS, MT, } \\
\text { ES, MG, SP, PR }\end{array}$ & $\begin{array}{l}\mathrm{Am}, \mathrm{Ca}, \mathrm{Ce}, \\
\mathrm{Ma}, \mathrm{Pa}\end{array}$ & $\mathrm{Ce}$ & $1,2,3$ \\
\hline $\begin{array}{l}\text { Centrolobium } \\
\text { tomentosum }\end{array}$ & Brasil & $\begin{array}{l}\text { BA, DF, GO, ES, MG, RJ, } \\
\text { SP, PR }\end{array}$ & $\mathrm{Ca}, \mathrm{Ce}, \mathrm{Ma}$ & Fes, Fod & 1,2 \\
\hline Dipteryx alata & Bolívia, Brasil & $\begin{array}{l}\text { PA, RO, TO, BA, MA, PI, } \\
\text { DF, GO, MS, MT, MG, SP }\end{array}$ & $\mathrm{Am}, \mathrm{Ca}, \mathrm{Ce}$ & $\mathrm{Ce}, \mathrm{Fes}$ & $1,2,3$ \\
\hline $\begin{array}{l}\text { Leptolobium } \\
\text { dasycarpum }\end{array}$ & Bolívia, Brasil & $\begin{array}{l}\text { RO, TO, BA, CE, MA, PI, } \\
\text { DF, GO, MS, MT, MG, SP }\end{array}$ & $\mathrm{Am}, \mathrm{Ce}$ & $\mathrm{Ce}$ & $1,2,3$ \\
\hline $\begin{array}{l}\text { Leptolobium } \\
\text { elegans }\end{array}$ & Bolívia, Brasil & GO, MS, MT, MG, SP, PR & $\mathrm{Ce}$ & $\mathrm{Ce}$ & $1,2,3$ \\
\hline $\begin{array}{l}\text { Machaerium } \\
\text { acutifolium }\end{array}$ & $\begin{array}{l}\text { Argentina, } \\
\text { Bolívia, Paraguai, } \\
\text { Venezuela, Brasil }\end{array}$ & $\begin{array}{l}\text { PA, RO, TO, BA, CE, MA, } \\
\text { PA, PI, DF, GO, MS, MT, } \\
\text { MG, SP, PR }\end{array}$ & $\begin{array}{l}\mathrm{Am}, \mathrm{Ca}, \mathrm{Ce}, \\
\mathrm{Ma}, \mathrm{Pa}\end{array}$ & $\mathrm{Ce}$ & $1,2,3,4$ \\
\hline $\begin{array}{l}\text { Machaerium } \\
\text { amplum }\end{array}$ & Bolívia, Brasil & $\begin{array}{l}\text { AC, AM, PA, RO, BA, CE, } \\
\text { MA, RN, DF, GO, MS, MT, } \\
\text { MG, SP }\end{array}$ & $\mathrm{Am}, \mathrm{Ce}, \mathrm{Ma}$ & $\mathrm{Ce}, \mathrm{Fes}$ & $1,2,3,4$ \\
\hline $\begin{array}{l}\text { Machaerium } \\
\text { brasiliense }\end{array}$ & Argentina, Brasil & $\begin{array}{l}\text { AM, AL, BA, MA, PE, DF, } \\
\text { GO, MT, ES, MG, RJ, SP, PR }\end{array}$ & $\begin{array}{l}\mathrm{Am}, \mathrm{Ca}, \mathrm{Ce}, \\
\mathrm{Ma}\end{array}$ & $\mathrm{Ce}, \mathrm{Fes}$ & $1,2,3,4$ \\
\hline Machaerium hirtum & Bolívia, Brasil & $\begin{array}{l}\text { AC, AM, PA, TO, AL, BA, } \\
\text { CE, MA, PA, PE, PI, RN, SE, } \\
\text { DF, GO, MS, MT, ES, MG, } \\
\text { RJ, SP, PR, SC }\end{array}$ & $\begin{array}{l}\mathrm{Am}, \mathrm{Ca}, \mathrm{Ce} \\
\mathrm{Ma}, \mathrm{Pa}\end{array}$ & $\mathrm{Ce}, \mathrm{Fes}$ & $1,2,3,4$ \\
\hline $\begin{array}{l}\text { Machaerium } \\
\text { nyctitans }\end{array}$ & $\begin{array}{l}\text { Argentina, Bolívia, } \\
\text { Brasil }\end{array}$ & $\begin{array}{l}\text { BA, ES, MG, RJ, SP, PR, } \\
\text { RS, SC }\end{array}$ & $\mathrm{Ce}, \mathrm{Ma}$ & Fes & $1,2,4$ \\
\hline $\begin{array}{l}\text { Machaerium } \\
\text { paraguariense }\end{array}$ & $\begin{array}{l}\text { Argentina, Bolívia, } \\
\text { Paraguai, Brasil }\end{array}$ & $\begin{array}{l}\text { BA, DF, GO, MS, MT, ES, } \\
\text { MG, RJ, SP, PR, RS, SC }\end{array}$ & $\mathrm{Ce}, \mathrm{Ma}$ & $\mathrm{Ce}, \mathrm{Fes}$ & $1,2,3,4$ \\
\hline $\begin{array}{l}\text { Machaerium } \\
\text { stipitatum }\end{array}$ & $\begin{array}{l}\text { Argentina, } \\
\text { Paraguai, Brasil }\end{array}$ & $\begin{array}{l}\text { BA, DF, GO, MS, ES, MG, } \\
\text { RJ, SP, PR, RS, SC }\end{array}$ & $\mathrm{Ce}, \mathrm{Ma}$ & Fes & $1,2,4$ \\
\hline $\begin{array}{l}\text { Machaerium } \\
\text { villosum }\end{array}$ & Bolívia, Brasil & $\begin{array}{l}\mathrm{BA}, \mathrm{CE}, \mathrm{PI}, \mathrm{DF}, \mathrm{GO}, \mathrm{MS}, \\
\mathrm{MG}, \mathrm{SP}, \mathrm{PR}\end{array}$ & $\mathrm{Ca}, \mathrm{Ce}, \mathrm{Ma}$ & $\mathrm{Ce}, \mathrm{Fes}$ & $1,2,4$ \\
\hline
\end{tabular}




\begin{tabular}{|c|c|c|c|c|c|}
\hline Espécie & $\begin{array}{l}\text { Distribuição } \\
\text { mundial }\end{array}$ & Distribuição no Brasil & $\begin{array}{l}\text { Dom.fitogeog. } \\
\text { Brasil }\end{array}$ & $\begin{array}{l}\text { Tipo } \\
\text { vegetação SP }\end{array}$ & Referências \\
\hline $\begin{array}{l}\text { Myroxylon } \\
\text { peruiferum }\end{array}$ & $\begin{array}{l}\text { Argentina, } \\
\text { Bolívia, Colômbia, } \\
\text { Equador, Guiana, } \\
\text { México, Peru, } \\
\text { Brasil }\end{array}$ & $\begin{array}{l}\text { BA, CE, PA, DF, GO, MS, } \\
\text { MT, ES, MG, RJ, SP, PR }\end{array}$ & $\mathrm{Ce}, \mathrm{Ma}$ & $\mathrm{Ce}, \mathrm{Fes}$ & $1,2,3$ \\
\hline Ormosia arborea & $\begin{array}{l}\text { Guiana Francesa, } \\
\text { Guiana, Venezuela, } \\
\text { Brasil }\end{array}$ & BA, GO, ES, MG, RJ, SP & $\mathrm{Ce}, \mathrm{Ma}$ & Fes & 1,2 \\
\hline $\begin{array}{l}\text { Platypodium } \\
\text { elegans }\end{array}$ & $\begin{array}{l}\text { Bolívia, Colômbia, } \\
\text { Panamá, Paraguai, } \\
\text { Venezuela, Brasil }\end{array}$ & $\begin{array}{l}\text { AC, AM, PA, RO, RR, TO, } \\
\text { BA, CE, MA, PI, SE, DF, } \\
\text { GO, MS, MT, ES, MG, RJ, } \\
\text { SP, PR, SC }\end{array}$ & $\begin{array}{l}\mathrm{Am}, \mathrm{Ca}, \mathrm{Ce}, \\
\mathrm{Ma}\end{array}$ & $\mathrm{Ce}$ & $1,2,3$ \\
\hline Pterodon pubescens & Brasil & $\begin{array}{l}\text { TO, BA, MA, PI, DF, GO, } \\
\text { MS, MT, MG, SP }\end{array}$ & $\begin{array}{l}\mathrm{Am}, \mathrm{Ca}, \mathrm{Ce}, \\
\mathrm{Pa}\end{array}$ & $\mathrm{Ce}$ & $1,2,3$ \\
\hline Sweetia fruticosa & $\begin{array}{l}\text { Bolívia, Paraguai, } \\
\text { Brasil }\end{array}$ & $\begin{array}{l}\text { BA, MA, MS, MT, ES, MG, } \\
\text { RJ, SP, PR }\end{array}$ & $\mathrm{Ca}, \mathrm{Ce}$, & $\mathrm{Ce}, \mathrm{Fes}$ & $1,2,3$ \\
\hline
\end{tabular}

\section{Chave para identificação dos táxons arbóreos de Papilionoideae ocorrentes em fragmentos do noroeste paulista}

1. Plantas armadas.

2. Arbustos; ramos com acúleos curvos

6.2 Machaerium amplum

2'. Árvores; ramos com acúleos retilíneos.

3. Folíolos com venação broquidódroma, alternos; raque foliar ferrugíneo-pilosa; sâmara falciforme 6.5 Machaerium nyctitans

3'. Folíolos com venação craspedódroma, subopostos; raque foliar fusco-tomentosa; sâmara cultriforme 6.4 Machaerium hirtum

1'. Plantas inermes.

4. Presença de glândulas, pontuações e/ou traços translúcidos no limbo.

5. Folíolos com glândulas peltadas na face abaxial (Fig. 2f), sem pontuações ou traços; núcleo seminífero do fruto com superfície espinescente (Fig. 2h) .........3 Centrolobium tomentosum

5'. Folíolos sem glândulas peltadas na face abaxial, com pontuações e/ou traços translúcidos; núcleo seminífero do fruto com superfície lisa.

6. Pontuações e traços translúcidos nos folíolos (Fig. 2n); fruto sâmara (Fig. 2o)

6'. Pontuações translúcidas areoladas no limbo, frutos de outros tipos.

7 Myroxylon peruiferum

7. Raque foliar alada; fruto drupa (Fig. 2k).

4 Dipteryx alata

7'. Raque foliar não alada; fruto criptosâmara (Fig. 3k) 10 Pterodon pubescens

4'. Ausência de glândulas, pontuações e/ou traços translúcidos no limbo.

8. Folíolos alternos.

9. Flores com alas e pétalas da carena semelhantes entre si; androceu pseudomonadelfo . 11 Sweetia fruticosa

9'. Flores com alas e pétalas da carena desiguais entre si; androceu diadelfo ou monadelfo.

10. Folíolos com venação camptódroma; androceu diadelfo; sâmara com núcleo seminífero apical (Fig. 3j) 9 Platypodium elegans

10'. Folíolos com venação broquidódroma; androceu monadelfo; sâmara com núcleo seminífero basal.

11. Folíolos com a face adaxial glabra e nítida; inflorescência do tipo racemo. 
12. Ramos com cicatrizes de catáfilos; folíolos ovais (Fig. 3c)

12’. Ramos sem cicatrizes de catáfilos; folíolos elípticos . 6.3 Machaerium brasiliense

11'. Folíolos com a face adaxial pilosa e opaca; inflorescência do tipo panícula.

13. Ramos sulcados, pilosos, sem lenticelas e com cicatriz estipular evidente; folíolos oblongos, lanceolados ou obovados, ápice agudo; cálice enegrecido (Fig. 3e)...

6.8 Machaerium villosum

13'. Ramos não sulcados, glabros, lenticelados e sem cicatriz estipular evidente; folíolos elípticos, ápice retuso, mucronado; cálice creme-esverdeado.

6.7 Machaerium stipitatum

8'. Folíolos subopostos e/ou opostos.

14. Corola não papilionácea (pétalas semelhantes entre si).

15. Folíolos ovais, face abaxial dos folíolos e frutos tomentosos

5.1 Leptolobium dasycarpum

15'. Folíolos oval-lanceolados, face abaxial dos folíolos e frutos glabros.

5.2 Leptolobium elegans

14'. Corola papilionácea (pétalas diferenciadas em vexilo, asas e carena).

16. Folíolos elípticos, venação broquidódroma; fruto sâmara ........ 6.1 Machaerium acutifolium

16'. Folíolos oblongos, venação camptódroma; fruto de outros tipos.

17. Raque foliar com tricomas ferrugíneos; folíolos com a face adaxial opaca; fruto legume (Fig. 3h); sementes bicolores ....................................................... 8 Ormosia arborea

17'. Raque foliar glabra; folíolos com a face adaxial nítida; fruto drupa ou legume samaróide; sementes de coloração uniforme.

18. Estipelas presentes; vexilo rosa; androceu diadelfo; fruto drupa

18'. Estipelas ausentes; vexilo azul; estames livres; fruto legume samaróide (Fig. 2d)

2 Bowdichia virgilioides

1. Andira vermifuga (Mart.) Benth., Comm. Legum. Gen.: 44-45. $1837 . \quad$ Fig. 2a-b

Árvores 3-6 m alt., inermes, caule rugoso, com estrias longitudinais, acinzentado. Ramos rugosos, hirsutos. Folhas com pecíolo 4,4-7,5 cm compr., glabro, não alado; raque 5,5-8,5 cm compr., cilíndrica, glabra, não alada; estípulas lineares, caducas; estipelas $3-4$ $\mathrm{mm}$ compr.; folíolos 3,6-6 × 2,2-3,7 cm, discolores, coriáceos, subopostos, oblongos, base subcordada, ápice retuso a emarginado, ambas as faces glabras, a adaxial nítida; ausência de glândulas, pontuações translúcidas e traços no limbo; venação broquidódroma, nervuras primárias e marginais proeminentes em ambas as faces; peciólulo 2-3 mm compr., pulverulento. Inflorescências racemosas, terminais e axilares; brácteas não observadas. Flores com pedicelo 3-4 $\mathrm{mm}$ compr., pulverulento; cálice campanulado, sépalas arroxeadas, pulverulentas; corola papilionácea, vexilo $1 \times 1 \mathrm{~cm}$, rosa, orbicular, base unguiculada, ápice emarginado, glabro com máculas lilases; asas $9 \times 4 \mathrm{~mm}$, oblongas, base oblíqua a auriculada, glabras; pétalas da carena $1,5 \times 0,9 \mathrm{~cm}$, oblongas, livres, glabras; androceu diadelfo; ovário glabrescente. Drupas ca. 5-6 cm compr., ovóides; sementes ca. 5-6 cm compr., de coloração uniforme, sem arilo.

Material examinado: Votuporanga, Faz. Primavera, 29.VIII.2007, fr., Rezende, A. et al. 5 (BOTU).

Material adicional: Brasília: Bacia do Rio São Bartolomeu, 24.VIII.1981, fl., Heringer, E.P. et al. 7341 (UEC). Minas Gerais: Januária, margem da Rod. BR-135, na saída de Januária para Itacarambi, 18.VIII.1994, fl., Árbocz, G.F. 664 (UEC).

Andira vermifuga pode ser reconhecida pelos folíolos coriáceos, discolores, com as nervuras primárias e marginais proeminentes em ambas as faces e pelo fruto do tipo drupa. Ocorre na Bolívia e no Brasil, onde é amplamente distribuída principalmente nos domínios de Cerrado e Caatinga, em fisionomias de Cerrado, Floresta Estacional Decidual e Floresta Estacional Semidecidual (Tab.1; Pennington 2003, BFG 2015). A espécie tem limite sul no estado de São Paulo, onde é distribuída principalmente no planalto ocidental (speciesLink 2015). No Noroeste paulista foi encontrada na borda de fragmentos de Cerradão. Floresce em agosto e frutifica em dezembro. 

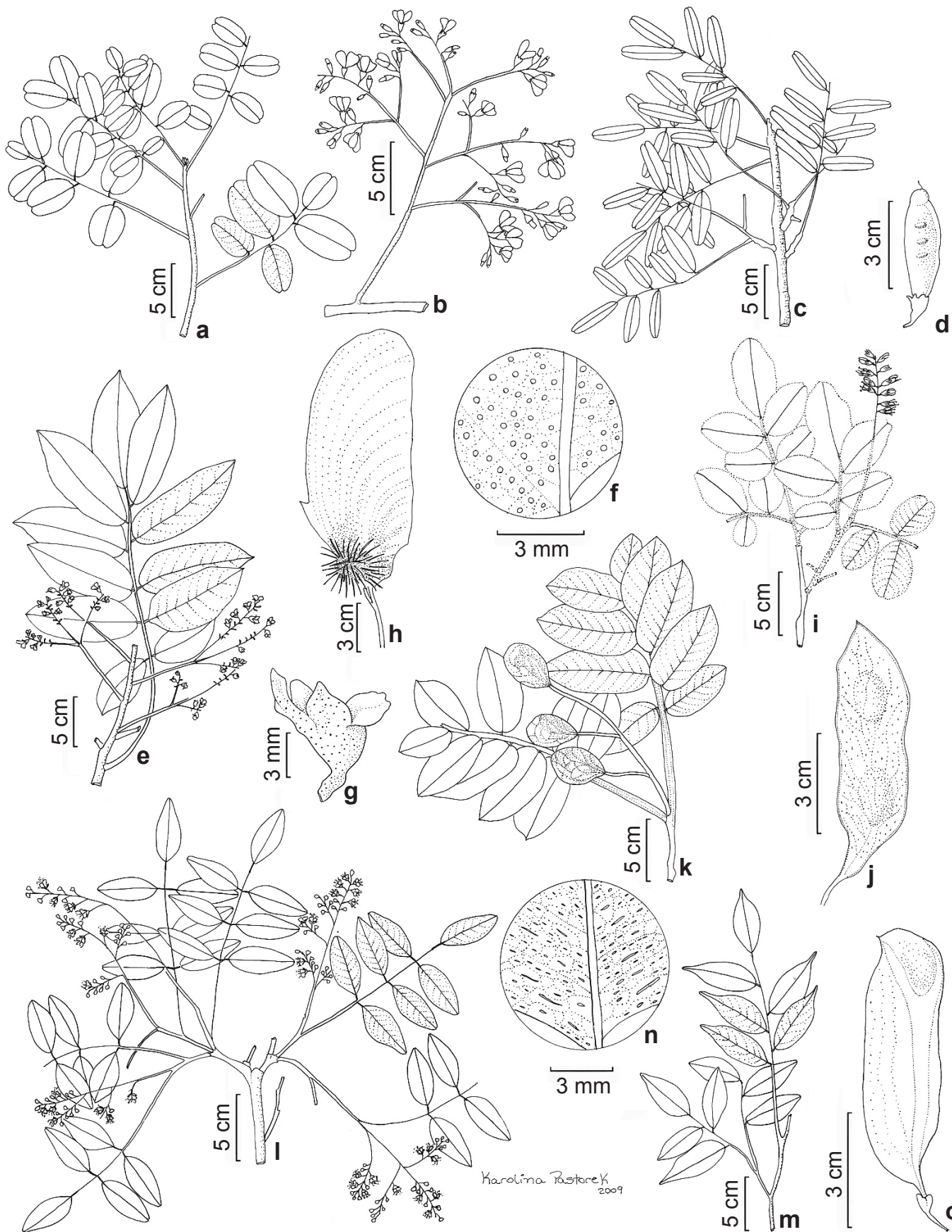

\section{.}


2. Bowdichia virgilioides Kunth, Nov. Gen. Sp. 6: 376-377. 1823.

Fig. $2 \mathrm{c}-\mathrm{d}$

Árvores 5-10 m alt., inermes, caule suberoso, castanho escuro. Ramos glabros a levemente suberosos, com estrias evidentes. Folhas com pecíolo 2-3 cm compr., canaliculado, pubérulo, não alado; raque $6-9,5 \mathrm{~cm}$ compr., cilíndrica, glabra, não alada; estípulas $5 \mathrm{~mm}$ compr.; estipelas ausentes; folíolos 3-6 × 1,5-1,9 cm, discolores, coriáceos, subopostos, oblongos, base obtusa, ápice emarginado, face adaxial glabra, nítida, face abaxial esparsamente tomentosa, com nervura central proeminente; ausência de glândulas peltadas, pontuações translúcidas e traços no limbo; venação broquidódroma; peciólulo 1-2 mm compr., espessado, esparsamente tomentoso. Inflorescências racemosas, terminais; brácteas deltóides, tomentosas. Flores com pedicelo 3-4 mm compr., sulcado, glabrescente; cálice turbinado-campanulado, sépalas violáceas, levemente tomentosas; corola papilionácea, vexilo $1,4 \times 1,4 \mathrm{~cm}$, azul, largo-orbicular, emarginado, glabro; asas 1,8 $\times 0,9 \mathrm{~cm}$, obovadas, glabras; pétalas da carena $1,5 \times 0,4 \mathrm{~cm}$, oblongas, livres, glabras; estames livres; ovário achatado, flavescente-piloso nas margens, estigma capitado. Legumes samaróides, 4,5-6 cm compr., estreitoalados, elípticos; sementes 1- compr. 1,7 cm, oblongas, compressas, de coloração uniforme, sem arilo.

Material examinado: Macaubal, Distrito de Ida Iolanda, Faz. Pauã, 21.XI.2007, fr., Martins, M.V. et al. 30 (SJRP); Planalto, Faz. Taperão, 23.IX.2007, fl., Stuchi, L. \& Neto, A.B.A. 879 (BOTU); Guaraçaí, reserva legal, assentamento do INCRA, 07. VIII. 1995, fr., Pereira-Noronha, M.R. 1603 (HISA).

Bowdichia virgilioides pode ser reconhecida pelos folíolos oblongos e discolores, com ápice retuso a emarginado e flores com corola azulada. Ocorre em vários países da América do Sul, com limite sul na Bolívia e Brasil (Tab. 1). No Brasil é amplamente distribuída nos vários domínios fitogeográficos, com maior densidade de registros nos domínios de Cerrado e Caatinga (BFG 2015; speciesLink 2015). O estado do Paraná representa o limite sul da espécie, e no estado de São Paulo esta ocorre principalmente no planalto ocidental (speciesLink 2015), em fisionomia de Cerrado (Durigan et al. 2004). No Noroeste paulista foi encontrada no interior de áreas de Cerradão, com flores em setembro e frutos em novembro.
3. Centrolobium tomentosum Guillem. ex Benth., J. Bot. 2: 66. 1840.

Fig. 2e-h

Árvores 4-15 m alt., inermes, caule suberoso, fissurado, acinzentado. Ramos lenticelados, tomentosos, com látex caramelo. Folhas com pecíolo $7-9,5 \mathrm{~cm}$ compr., tomentoso; raque $20-30 \mathrm{~cm}$ compr., cilíndrica, tomentosa, não alada; estípulas deltóides, tomentosas, caducas; estipelas $22 \mathrm{~mm}$ compr.; folíolos 8,5-13,5 × 3,5-5 cm, concolores, coriáceos, opostos, oblongo-lanceolados, base arredondada, ápice cuspidado, tricomas hirsutos e esbranquiçados em ambas as faces, presença de glândulas peltadas na face abaxial, opaca, sem pontuações ou traços; venação broquidódroma; peciólulo 3-5 mm compr., piloso. Inflorescências paniculadas, terminais; brácteas ovadas, ápice agudo, ferrugíneo-tomentosas. Flores com pedicelo ca. $3 \mathrm{~mm}$ compr., ferrugíneo-tomentoso; cálice campanulado, sépalas externamente castanho-escuras, ferrugíneotomentosas, com pontuações douradas, internamente verdes, estriadas, tomentosas; corola papilionácea, vexilo $1,8 \times 1,5 \mathrm{~cm}$, amarelo, estriado, orbicular, ápice emarginado, base curto-unguiculada, glabro, mácula alva; asas 1,7 × 1,8 cm, oblongas, glabras; pétalas da carena $1,9 \times 0,6 \mathrm{~cm}$, auriculadas, glabras; androceu monadelfo; ovário giboso com tricomas glandulares. Sâmaras 10-25 cm compr., castanhoclaras, ala apical falcada a cultriforme, tomentosas, oblongas, estriadas, núcleo seminífero basal, com superfície espinescente; sementes 1,5-2,5 cm compr., reniformes, rugosas, de coloração uniforme, sem arilo.

Material examinado: Matão, Faz. Cambuy, 08.II.2008, fl e fr., Martins, M.V. 72 (BOTU).

Material adicional: Agudos, Faz. Santa Rita, 16.VII.1998, fl., Assis, P.F. de \& Christianini, S.R. 221 (UEC).

Centrolobium tomentosum é facilmente reconhecida pelas glândulas peltadas douradas na face abaxial dos folíolos e pelas sâmaras com acúleos na região do núcleo seminífero. Restrita ao Brasil, a espécie é distribuída desde o litoral da Bahia até o estado do Paraná, em domínio de Mata Atlântica, apresenta registros pontuais na região central (Tab.1; Pirie et al. 2009; BFG 2015; speciesLink 2015). No estado de São Paulo distribui-se comumente nas formações florestais do interior, com poucos registros nas formações litorâneas (speciesLink 2015), sendo relacionada para Floresta Estacional Semidecidual e Floresta Ombrófila Densa (Durigan et al. 2012; BFG 2015). No Noroeste paulista ocorre em áreas de Floresta Estacional Semidecidual, com floração de janeiro a abril e frutificação de março a setembro. 


\section{Dipteryx alata Vogel, Linnaea 11: 383. 1837.}

Fig. $2 \mathrm{k}$

Árvores 6-15 m alt., inermes; caule suberoso, castanho claro. Ramos lenticelados, glabros, com cicatrizes foliares. Folhas com pecíolo $6-11 \mathrm{~cm}$ compr., alado, piloso; raque 12,5-24 cm compr., alada, glabrescente; estípulas e estipelas não observadas; folíolos (7-12), 6,4-11 × 3-5,2 cm, concolores, coriáceos, subopostos, oval-elípticos, base arredondada, assimétrica, ápice cuspidado, faces glabras, limbo foliar com pontuações translúcidas areoladas, sem glândulas peltadas, face abaxial com a nervura principal proeminente; venação broquidódroma; peciólulos ca. $1 \mathrm{~mm}$ compr., retorcidos, pubérulos. Inflorescências paniculadas, terminais; brácteas e bractéolas não observadas. Flores com pedicelo $1 \mathrm{~mm}$ compr., glabro; cálice campanulado, sépalas cremeesverdeadas, pontuadas, 3 fusionadas e 2 livres; corola papilionácea, vexilo $0,6 \times 0,8 \mathrm{~cm}$, alvo, orbicular, ápice emarginado; asas $0,7 \times 0,4 \mathrm{~cm}$, oblongas, glabras; pétalas da carena $0,8 \times 0,3 \mathrm{~cm}$, oblongas, livres, glabras; androceu monadelfo; ovário glabrescente. Drupas 2-5-3 cm compr., ovóides, castanho-claro, glabras, com superfície lisa; sementes $2,5-3,5 \mathrm{~cm}$ compr., oblongas, de coloração uniforme, sem arilo.

Material examinado: Turmalina, Faz. São João, 23.I.2008, fl., Stuchi, L. \& Neto, A.B.A. 924 (BOTU); Votuporanga, Estação Experimental do IAC, 29.XI.1994, fr., Bernacci, L.C. et al. 812 (IAC); Faz. Primavera, 16.II.2008, fr., Stranghetti, V. et al. 20 (BOTU); 6.III.2008, fr., Stranghetti, V. et al. 03 (BOTU).

Dipteryx alata é uma espécie facilmente reconhecida pelo pecíolo e raque foliares alados. Ocorre na Bolívia e no Brasil, onde é amplamente coletada ao longo do domínio Cerrado, ocorrendo também nos domínios Caatinga e Amazônia (Tab.1; BFG 2015; speciesLink 2015). No estado de São Paulo ocorre em fisionomias de Cerrado, principalmente no planalto ocidental (Durigan et al. 2004; speciesLink 2015). No Noroeste paulista a espécie foi encontrada em áreas de Cerradão nas bordas dos fragmentos. A floração foi observada de outubro a janeiro e a frutificação de setembro a outubro.

5. Leptolobium Vogel, Linnaea 11: 388. 1837.

Árvores, arbustos ou subarbustos. Folhas imparipinadas ou raramente paripinadas; estípulas e estipelas caducas; folíolos opostos ou subopostos. Inflorescências paniculadas, terminais, às vezes precedidas por racemos ou panículas axilares; brácteas e bractéolas presentes, glândula na inserção do pedicelo e bractéolas. Flores actinomorfas ou levemente zigomorfas, subsésseis ou curto-pediceladas; corola não papilionácea; estames livres; ovário estipitado, óvulos 1-3, estigma punctiforme. Frutos legumes samaróides.

O gênero Leptolobium, restabelecido por Rodrigues \& Tozzi (2008), está subordinado à tribo Sophoreae. É exclusivamente neotropical, com 11 espécies no Brasil e duas espécies no estado de São Paulo, que foram encontradas no noroeste paulista (BFG 2015).

5.1. Leptolobium dasycarpum Vogel, Linnaea 11: 388. 1837.

Fig. 2i-j

Árvores 3-10 m alt., inermes, caule suberoso, castanho com fissuras longitudinais. Ramos velutíneos. Folhas com pecíolo 1,5-6 cm compr., tomentoso; raque $3,2-10 \mathrm{~cm}$, cilíndrica, tomentosa; estípulas $3-5 \mathrm{~mm}$ compr.; estipelas 1,5-2 mm compr.; folíolos 5-10 × 2-9 cm, discolores, coriáceos, ovais, base obtusa, ápice emarginado, face adaxial glabra, face abaxial tomentosa, nervura principal proeminente, sem pontuações; venação broquidódroma; margem ciliada; peciólulo 1-2 mm, tomentoso. Inflorescências paniculadas, terminais; brácteas lineares, caducas. Flores actinomorfas, pedicelo $1 \mathrm{~mm}$ compr., tomentoso; sépalas esverdeadas; pétalas alvas, obovadas, glabrescentes; ovário tomentoso, oblongo-elíptico. Legumes samaróides 4-7 cm compr., oblongos, tomentosos; sementes não observadas.

Material examinado: Macaubal, Distrito de Ida Iolanda, Faz. Pauã, 22.XI.2007, fr., Stuchi, L. \& Neto, A.B.A. 820 (BOTU); Paulo de Faria, Rod. em direção a Riolândia, 10.X.1994, fl., Maestro, A.L. \& Silveira, A.M. 68 (UEC); Mogi Guaçu, fazenda Campininha, 22.XII.1984. fl., Kirizawa, M. et al. 1348 (UEC).

Leptolobium dasycarpum é reconhecida pela corola não papilionácea e pelos folíolos que variam de ovais a elípticos. Ocorre na Bolívia e no Brasil, no domínio Cerrado e em áreas de transição com a Caatinga (Tab1.; Rodrigues \& Tozzi 2012; BFG 2015). Distribui-se principalmente ao longo do planalto ocidental do estado de São Paulo, que representa o limite sul para a distribuição da espécie (speciesLink 2015). No Noroeste paulista foi encontrada em formações de Cerradão, no interior dos fragmentos. A floração foi observada de outubro a dezembro e a frutificação de fevereiro a maio. 
5.2. Leptolobium elegans Vogel, Linnaea 11: 390. 1837.

Fig. 21

Árvores 2-9 m alt., inermes, caule suberoso, castanho. Ramos suberosos, glabros, não lenticelados. Folhas com pecíolo 3-6 cm compr., glabras; raque 6-10 cm compr., cilíndrica, glabra; estípulas 4-6 mm compr.; estipelas $1-1,5$ mm compr.; folíolos 2-8 × 1-4 cm, discolores, coriáceos; oval-lanceolados, base cuneada, ápice emarginado, glabros, sem pontuações; venação broquidódroma; margem não ciliada; peciólulo 2-6 mm compr., glabro. Inflorescências paniculadas, terminais e axilares; brácteas caducas não observadas; bractéolas lineares. Flores actinomorfas, pediceladas, pedicelo de $1 \mathrm{~mm}$ compr., tomentoso; sépalas creme-esverdeadas; pétalas creme, obovadas, glabras; ovário glabro, oblongo-elíptico. Legumes samaróides 2-6 $\mathrm{cm}$ compr., oblongos, glabros; sementes não observadas.

Material examinado: Macaubal, Distrito de Ida Iolanda, Faz. Pauã, 15.III. 2007, fr., Stranghetti, V. et al. 17 (BOTU); Paulo de Faria, direção a Riolândia, 10.X.1994, fl., Maestro, A.L. \& Silveira, A.M. 75 (ESA); Planalto, Faz. Taperão, 12.IX.2007, fr., Stuchi, L. \& Neto, A.B.A. 348 (BOTU); Votuporanga, Estação experimental do IAC, 28.XI.1994, fl., Bernacci, L.C. et al. 760 (IAC).

Leptolobium elegans é reconhecida pela corola não papilionácea e pelos folíolos que variam de elípticos a oval-lanceolados. Ocorre na Argentina, Paraguai e no Brasil, onde distribuise em domínio de Cerrado e em florestas baixas semideciduais (Rodrigues \& Tozzi 2012), nas regiões Centro-Oeste e Sudeste, limitando ao Sul no estado do Paraná (BFG 2015). No estado de São Paulo a espécie é encontrada exclusivamente em fisionomias de Cerrado (Tab. 1; Durigan et al. 2012). Na região Noroeste foi encontrada em fragmentos de Cerradão, com floração de outubro a dezembro e frutificação de março a maio.

6. Machaerium Pers., Syn. Pl. 2(2): 276. 1807.

Árvores eretas ou escandentes (ramos flexíveis), armadas ou inermes. Folhas imparipinadas; estípulas espinescentes ou não, caducas; estipelas ausentes; folíolos alternos ou subopostos; ausência de glândulas, pontuações translúcidas e traços no limbo. Inflorescências racemosas fasciculadas ou paniculadas, terminais e/ou axilares; brácteas presentes ou ausentes; bractéolas presentes. Flores zigomorfas, sésseis a pediceladas; corola papilionácea, lilás, vinácea, creme-esverdeada ou branca; androceu monadelfo; ovário estipitado, disco nectarífero na base. Fruto núcula ou sâmara, cultriforme ou falciforme, curva ou não na região do núcleo seminífero basal, ala reticulado-venosa; sementes reniformes, lisas ou rugosas, de coloração uniforme, sem arilo.

Gênero subordinado a tribo Dalbergieae sens. lat. (Lima 1989-1990; Sartori \& Tozzi 1998), com 130 espécies neotropicais (Klitgaard \& Lavin 2005). No Brasil ocorrem 71 espécies, 18 no estado de São Paulo (BFG 2015). No noroeste paulista foram encontradas oito espécies de Machaerium.

6.1 Machaerium acutifolium Vogel, Linnaea 11: 187.1837.

Iconografia: Bentham (1862: prancha 72)

Árvores 8-12 m alt., inermes, caule suberoso, castanho escuro. Ramos lenticelados, levemente sulcados, glabros. Folhas com pecíolo de 2-4 cm compr., glabro; raque $8,5-15 \mathrm{~cm}$ compr., cilíndrica, glabra; estípulas e estipelas caducas, não observadas; folíolos 6-9,8 × 2-2,5 $\mathrm{cm}$, concolores, cartáceos, subopostos, elípticos, base arredondada, ápice agudo, mucronado, face adaxial glabra, nítida, face abaxial hirsuta, tomentosa sobre a nervura principal, sem pontuações translúcidas; venação broquidódroma; peciólulo 3-4 mm compr., glabro. Inflorescências paniculadas, axilares, pendentes; brácteas ausentes; bractéolas elípticas, esparsamente tomentosas. Flores sésseis; cálice campanulado, esverdeado; corola com vexilo 5-7 × 3-6 mm, suboval, externamente enegrecido, seríceo, internamente esbranquiçado, glabro, exceto no ápice esparso-tomentoso; asas $4 \times 2 \mathrm{~mm}$, oblongas; pétalas da carena semelhantes às asas; ovário curtamente estipitado, velutino. Sâmaras 5,5-8 cm compr., falciformes, oblongas, região seminífera basal, rugosa, asas com pontuações escuras; sementes 1-1,7 cm compr., rugosas.

Material examinado: Macaubal, Distrito de Ida Iolanda, Faz. Pauã, 20.XI.2007, fl., Martins, M.V. 37 (BOTU); Votuporanga, Faz. Primavera, 15.III.2008, fr., Stranghetti, V. et al. 41 (BOTU).

Machaerium acutifolium é caracterizada pelos folíolos elípticos, frutos falciformes e oblongos, rugosos na região seminífera. Ocorre em vários países da América do Sul (Tab. 1) e no Brasil é amplamente coletada desde a região Norte e Nordeste até o Sul (Paraná), principalmente nos domínios Cerrado, Caatinga e Mata Atlântica, com ocorrências também no Pantanal e Amazônia (BFG 2015; speciesLink 2015). No estado de 
São Paulo a espécie é considerada exclusiva de fisionomias de Cerrado, com registros concentrados no planalto ocidental (Sartori \& Tozzi 1998; Durigan et al. 2012, speciesLink 2015). No Noroeste paulista foi encontrada principalmente em áreas de Cerradão, no interior e nas bordas dos fragmentos. A floração foi observada em novembro e dezembro e a frutificação em março.

6.2 Machaerium amplum Benth., Commentat. Legum. Gen. 33. 1837.

Fig. 3a-b

Arvoretas 1,5-3 m alt., armadas, caule liso, acinzentado. Ramos flexível (escandentes), com acúleos curvos, acinzentados, glabros. Folhas com pecíolo 1-2 cm compr., glabro; raque 4-8 cm compr., cilíndrica, glabra; estípulas espinescentes; folíolos 2,6-4,5 × 1-1,6 cm, discolores, cartáceos, alternos, oblongos; base arredondada, ápice obtuso, mucronado, faces adaxial e abaxial glabras e opacas; venação craspedódroma; peciólulo 2-3 mm compr., rugoso, esparso-tomentoso. Inflorescências paniculadas, terminais e axilares. Flores com pedicelo velutino, 3 $\mathrm{mm}$; cálice externamente esparso-tomentoso; corola com vexilo 5,4-8,6 × 5-6 mm, oval, lilás com mácula branca no centro, externamente esparso-seríceo; asas 6-9 × 2-3 mm, elípticas; pétalas da carena semelhantes às asas; ovário incano-velutino. Sâmaras 5-7 cm compr., cultriformes, região seminífera basal, esparso-tomentoso; sementes 1-1,5 cm compr., lisas. Material examinado: Onda Verde, Faz. São João, 29.VI.1994, fl., Tamashiro, J.Y. et al. 273 (UEC); Paulo de Faria, Estação Ecológica, 27.IV.1993, fl., Stranghetti, V. 100 (UEC); Votuporanga, Faz. vizinha do IAC, 16.V.1995, fl., Bernacci, L.C. et al. 1651 (IAC); Faz. Primavera, 15.VIII.2007, fr., Stuchi, L. \& Neto, A.B.A., 899 (BOTU).

Machaerium amplum é reconhecido pelos acúleos curvos nos ramos e hábito escandente. Ocorre na Bolívia e no Brasil (Tab.1), onde se distribui em domínios diversos, desde a região Norte até o Sudeste, com limite sul nos estados de São Paulo e Mato Grosso do Sul (BFG 2015; speciesLink 2015). No estado de São Paulo há um predomínio de coletas na região Noroeste (Sartori \& Tozzi 1988; speciesLink 2015) onde foi encontrada em Floresta Estacional Semidecidual e em Cerradão, no interior e borda dos fragmentos. A floração foi observada de maio a julho e a frutificação de junho a agosto.

6.3 Machaerium brasiliense Vogel, Linnaea 11: 185. 1837.

Iconografia: Bentham (1862: prancha 74)

Árvores 6-15 m alt., inermes, caule suberoso, súber descamante, castanho escuro, resina viscosa.
Ramos lenticelados, glabrescentes, sem cicatrizes de catáfilos. Folhas com pecíolo 1,1-3,2 cm compr., viloso; raque 3,2-6,2 cm, sulcada, vilosa; estípulas e estipelas caducas, não observadas; folíolos 3,7-5,7 × 1,3-2,4 cm, concolores, cartáceos, alternos, elípticos, base assimétrica, ápice acuminado, face adaxial glabra e nítida, face abaxial tomentosa, ferrugíneovilosa sobre a nervura principal, opaca; ausência de glândulas ou pontuações translúcidas no limbo; venação broquidódroma; pecíolo com pilosidade alva; peciólulo 2-4 mm, rugoso, esparso ferrugíneoviloso. Inflorescências racemosas e axilares; brácteas triangulares, côncavas, externamente estriadas, pubérulas; bractéolas lineares, ferrugíneo-vilosas. Flores com pedicelo tomentosos, $2 \mathrm{~mm}$; cálice ferrugíneo-tomentoso externamente; corola com vexilo $7 \times 5 \mathrm{~mm}$, orbicular, externamente enegrecido, seríceo na metade superior, internamente cremeesverdeado; asas $7 \times 3 \mathrm{~mm}$, oblongas, tomentosas; pétalas da carena semelhantes as asas; ovário ferrugíneo-viloso. Sâmaras 4,9-8,5 cm compr., falciformes, asas oblongas, reticuladas, às vezes com pontuações escuras, região seminífera basal, castanhas; sementes 1-1,4 cm compr., rugosas.

Material examinado: Paulo de Faria, Estação Ecológica, 23.XI.1993, fl. e fr., Sciamarelli, A. 29110 (UEC); Turmalina, Faz. São João, 24.I.2008, fl., Stuchi, L. \& Neto, A.B.A. 889 (BOTU).

Machaerium brasiliense pode ser reconhecido pelos folíolos elípticos com ápice acuminado e inflorescências racemosas. A espécie ocorre na Argentina e no Brasil, onde é amplamente distribuída, do Nordeste ao Sul, nos domínios: Amazônia, Caatinga, Cerrado e Mata Atlântica (Tab.1; BFG 2015; speciesLink 2015). No estado de São Paulo as coletas estão concentradas na região central e sudeste (speciesLink 2015) e na região Noroeste foi encontrada em Floresta Estacional Semidecidual e Cerradão, no interior dos fragmentos. A floração foi observada em agosto e setembro e a frutificação em fevereiro e novembro.

6.4 Machaerium hirtum (Vell.) Stellfeld, Tribuna Farm. 14(12): 246. 1946.

Iconografia: Bentham (1862: prancha 67).

Árvores 3-6 m alt., armadas, caule liso, castanho. Ramos com acúleos retilíneos, acinzentados, tomentosos. Folhas com pecíolo $1 \mathrm{~cm}$ compr., tomentoso; raque $7-10 \mathrm{~cm}$ compr., cilíndrica, fusco-tomentosa, estípulas espinescentes; folíolos 9-23 × 3-5 mm, discolores, cartáceos; subopostos, oblongos, base oblíqua, ápice emarginado, mucronado, face adaxial 

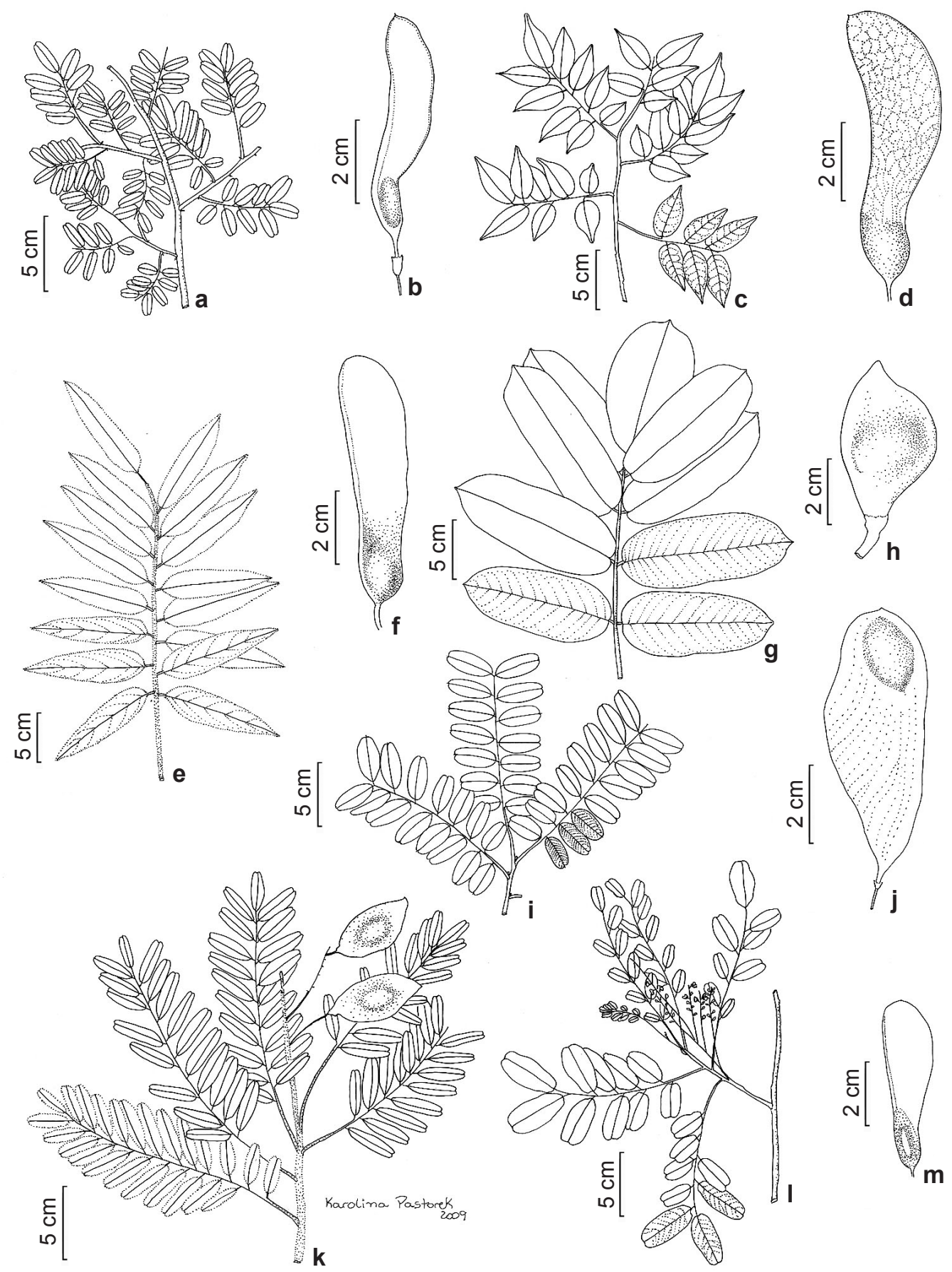

Figura 3 - a-b Machaerium amplum - a. ramo (Stuchi \& Neto 899); b. fruto (Tamashiro et al. 273). c-d Machaerium paraguariense - c. ramo (Stranghetti 171); d. fruto (Bernacci et al. 769). e-f Machaerium villosum - e. folha; f. fruto (e-f Bernacci 25.874). g-h Ormosia arborea - g. folha (Martins et al. 155); h. fruto (Kuhlmann 520). i-j Platypodium elegans - i. ramo (Martins 43); j. fruto (Martins 58). k Pterodon pubescens - ramo com fruto (Martins 70). 1-m Sweetia fruticosa-1. ramo com inflorescência (Rodrigues et al. 1202). m. fruto (Stuchi \& Neto 1052).

Figure 3 - a-b Machaerium amplum - a. leafy branch (Stuchi \& Neto 899); b. fruit (Tamashiro et al. 273). c-d Machaerium paraguariense - c. leafy branch (Stranghetti 171); d. fruit (Bernacci et al. 769). e-f Machaerium villosum - e. leaves; f. fruit (e-f Bernacci 25.874). g-h Ormosia arborea - g. leaves (Martins et al. 155); h. fruit (Kuhlmann 520). i-j Platypodium elegans - i. leafy branch (Martins 43); j. fruit (Martins 58). k. Pterodon pubescens - leafy branch with fruit (Martins 70). 1-m Sweetia fruticosa - 1. flowering branch (Rodrigues et al. 1202). m. fruit (Stuchi \& Neto 1052). 
glabra, face abaxial tomentosa, ambas opacas; venação craspedódroma; peciólulo $1 \mathrm{~mm}$ compr., tomentoso. Inflorescências paniculadas, terminais e axilares; brácteas ausentes; bractéolas orbiculares. Flores com pedicelos tomentosos, $1 \mathrm{~mm}$ de compr.; cálice com lobos desiguais, vináceos, externamente pubérulos; corola com vexilo $7 \times 5 \mathrm{~mm}$, oblongo, lilás com mácula central de cor creme, asas $8 \times$ $5 \mathrm{~mm}$, elípticas, tomentosas no dorso; pétalas da carena semelhantes às asas; ovário curtamente estipitado, incano-velutino. Sâmaras 4,5-6 cm compr., cultriformes, região seminífera basal, asas esparso-tomentosas; sementes 1,4-2 cm compr., rugosas.

Material examinado: São José do Rio Preto, estrada sentido Matão, 7.II.2008, fl., Martins, M.V. 69 (BOTU); Santo Antônio do Aracanguá, Distrito de Vicentinópolis, Faz. Rancho Alegre, 19.II.2008, fl., Martins, M.V. 73 (BOTU); São João de Iracema, Distrito de Magda, Faz. São Francisco, 17.VI. 2008, fr., Martins, M.V. 103 (BOTU); Votuporanga, Estação experimental IAC, 15.X.1995, fl., Bernacci, L.C. et al. 1633 (IAC).

Machaerium hirtum é caracterizada pelos folíolos oblongos, pelos acúleos retilíneos e achatados e pelo hábito arbóreo. Ocorre na Bolívia e no Brasil, onde é amplamente distribuída nos domínios Mata Atlântica, Caatinga, Cerrado e Pantanal (Tab.1), com registros pontuais no domínio Amazônia (BFG 2015; speciesLink 2015). Distribui-se no estado de São Paulo em fisionomias de Cerrado e Floresta Estacional Semidecidual (Sartori \& Tozzi 1998; speciesLink 2015). No Noroeste paulista foi encontrada nas bordas dos fragmentos de ambas as fisionomias, com floração de janeiro a maio e frutificação em junho e julho. A iconografia aqui citada para $M$. hirtum, é tratada na Flora Brasiliensis (Bentham 1862) como $M$. angustifolium Vogel. Lima (1995) sinonimizou M. angustifolium em M. hirtum.

6.5 Machaerium nyctitans (Vell.) Benth., Commentat. Legum. Gen. 34. 1837.

Iconografia: Sartori \& Tozzi (1998: fig. 8)

Árvores 4-12 m alt., armadas, caule suberoso, castanho claro. Ramos com acúleos retilíneos, lenticelados, esparso-tomentosos. Folhas com pecíolo 1,5-2,5 cm compr., ferrugíneo-tomentoso; raque $8-11 \mathrm{~cm}$ compr., cilíndrica, tomentosa, tricomas ferrugíneos; estípulas espinescentes; folíolos 3-5 × 0,8-1,8 cm, discolores; cartáceos, alternos, oblongos, base arredondada ou subcordada, ápice obtuso, com pequeno mucro; face adaxial pubérula, face abaxial tomentosa no limbo e ferrugíneo-tomentosa na nervura principal, ambas as faces opacas; venação broquidódroma; peciólulo $1 \mathrm{~mm}$ compr., ferrugíneo-tomentoso. Inflorescências paniculadas, terminais e axilares; brácteas triangulares, ferrugíneo-tomentosas; bractéolas oboval-lanceoladas, ferrugíneotomentosas. Flores sésseis; cálice ferrugíneotomentoso; corola com vexilo $8,2 \times 6,4 \mathrm{~mm}$, alvo, obovado, externamente ferrugíneo-tomentoso; asas $6,5 \times 2 \mathrm{~mm}$, elípticas; pétalas da carena 8 mm, semi-elípticas; ovário velutino. Sâmaras 6-9 $\mathrm{cm}$ compr., falciformes, região seminífera basal, enegrescida, asas ferrugíneo-tomentosas; sementes $1,5-2 \mathrm{~cm}$ compr., rugosas.

Material examinado: Matão, Faz. Cambuy, 26.III.2008, fl., Martins, M.V. 91 (BOTU); Pindorama, Estação Experimental, 26.XI.1993, fr., Sartori, A. 29140 (UEC).

Machaerium nyctitans é caracterizada pelo revestimento ferrugíneo-tomentoso nas inflorescências, folhas e frutos e pelo núcleo seminífero do fruto enegrescido. Ocorre na Argentina, Bolívia e Brasil, onde distribui-se desde a Bahia até o Rio Grande do Sul, principalmente em domínio Mata Atlântica, com ocorrências pontuais em domínio Cerrado (Tab. 1; BFG 2015; speciesLink 2015). No estado de São Paulo é amplamente distribuída principalmente em sua porção oriental, em fisionomias de Floresta Estacional Semidecidual (Sartori \& Tozzi 1998; speciesLink 2015). Na região Noroeste foi encontrada no interior e nas bordas dos fragmentos de Floresta Estacional Semidecidual. A floração foi observada de fevereiro a maio e a frutificação em março a dezembro.

6.6 Machaerium paraguariense Hassl., Bull. Herb. Boissier, sér. 2, 7: 358-359. $1907 . \quad$ Fig. 3c-d

Árvores 5-20 m alt., inermes, caule suberoso, castanho. Ramos lenticelados, esparso-tomentosos, com cicatrizes dos catáfilos. Folhas com pecíolo 1,1-3,4 cm compr., viloso escurecido; raque 6,8-10 cm compr., cilíndrica, vilosa; estípulas caducas, não observadas; folíolos 4,1-7,5 × 1,5-3 $\mathrm{cm}$, concolores, cartáceos, alternos, ovais, base arredondada, ápice acuminado; face adaxial glabra e nítida, face abaxial esparso-tomentosa, tricomas ferrugíneos sobre a nervura principal; venação broquidódroma; peciólulo 2-4 mm compr., rugoso, esparso ferrugíneo. Inflorescências racemosas, axilares; bractéolas e brácteas não observadas. Flores sésseis; cálice ferrugíneo-tomentoso externamente; corola com vexilo 7,3 $\times 6,3 \mathrm{~mm}$, alvo, orbicular; asas $6,5 \times 2,2 \mathrm{~mm}$, elípticas; asas 
e pétalas da carena desiguais; pétalas da carena 6 $\times 2 \mathrm{~mm}$; ovário pubérulo. Sâmaras 4,5-6,5 cm, falciformes, região seminífera basal, castanhas; sementes 1,5-2 cm compr., rugosas.

Material examinado: Paulo de Faria, Estação ecológica, 18.VIII.1993, fr., Stranghetti,V. 171 (UEC); 23.XI.1993, fl., Stranghetti, V. 237 (UEC); Votuporanga, Estrada para Candora, 26.VI.1992, fr., Lorenzi, H. 28450 (UEC); Faz. Experimental do IAC, 29. XI. 1994, fr., Bernacci, L.C. et al. 769 (UEC); Faz. Primavera, 11.VII.2007, fr., Stuchi, L. \& Neto, A.B.A.17 (BOTU).

Machaerium paraguariense caracterizase pelas cicatrizes de catáfilos nos ramos e a inflorescências racemosas. Ocorre na Argentina, Bolívia, Paraguai e Brasil, onde distribui-se desde o sul da Bahia até o Rio Grande do Sul, no domínio Mata Atlântica e na região Centrooeste, no domínio Cerrado (Tab.1; BFG 2015; speciesLink 2015). No estado de São Paulo há predomínio de registros na região Noroeste (speciesLink 2015), onde foi encontrada em Floresta Estacional Semidecidual e Cerradão, na borda e no interior dos fragmentos. A floração foi observada em janeiro e a frutificação de agosto a novembro.

6.7 Machaerium stipitatum (DC.) Vogel, Linnaea 11: 189. 1837.

Iconografia: Sartori \& Tozzi (1998: fig 9)

Árvores 4,5-8 m alt., inermes, caule suberoso, castanho claro. Ramos lenticelados, glabros, não sulcados, cicatriz estipular não evidente. Folhas com pecíolo 1,4-1,8 cm compr., glabrescente; raque 5,5-7 cm compr., cilíndrica, glabrescente; estípulas e estipelas caducas, não observadas; folíolos 2,4-4,6 × 1,4-1,9 cm, glaucos, concolores, cartáceos, alternos, elípticos, base arredondada, ápice retuso, mucronado; face adaxial pilosa, opaca e com nervuras impressas, face abaxial serícea; ausência de glândulas ou pontuações translúcidas no limbo; venação broquidródoma; peciólulo 2-4 mm, rugoso, tomentoso. Inflorescências paniculadas, terminais e axilares; brácteas ausentes; bractéolas oblongas, tomentosas. Flores sésseis; cálice campanulado, cremeesverdeado, esparso-tomentoso; corola com vexilo $5 \times 3 \mathrm{~mm}$, creme, obovado, seríceo; asas 5 $\times 1 \mathrm{~mm}$, oblongas; pétalas da carena semelhantes às asas; ovário esparso-viloso. Sâmaras 3,5-5,5 cm compr., falciformes, glabras, ápice da asa arredondado com pequeno mucro, região seminífera basal, castanho-escura; sementes 1-1,5 cm compr., rugosas.
Material examinado: Distrito de Vicentinópolis, Faz. Rancho Alegre, Santo Antônio do Aracanguá, fl., 18.II.2008, Martins, V.M. 75 (BOTU); Distrito de São João de Iracema, Faz. São Francisco, fr., 17. VI.2008, Martins, V.M. 95 (BOTU); Matão, Faz. Cambuhy, fl., 14.IV.1994, Souza,V.C. et al. 5683 (UEC); Paulo de Faria, Estação ecológica, 3.V.1991, fl., Stranghetti, V. 32\& Guimarães, P. (UEC); Pindorama, Estação ecológica, 26.XI.1993, fr., Sartori, A.L.B. 30434 (UEC); São José do Rio Preto, Instituto Penal Agrícola, 24.XI.1993, fr., Sciamarelli, A. et al. 29132 (UEC).

Machaerium stipitatum pode ser reconhecido pelos folíolos elípticos com ápice retuso e mucronado. Ocorre na Argentina, Paraguai e Brasil, onde distribui-se principalmente nas regiões CentroOeste, Sudeste e Sul, nos domínios Mata Atlântica e Cerrado (Tab.1; BFG 2015; speciesLink 2015). É amplamente coletada no estado de São Paulo, em fisionomia de Floresta Estacional Semidecidual (Sartori \& Tozzi 1998; speciesLink 2015). No Noroeste paulista foi encontrada no interior e na borda dos fragmentos desta fisionomia, com floração de fevereiro a maio e frutificação em junho.

6.8. Machaerium villosum Vogel, Linnaea 11: 189. 1837.

Fig. $3 \mathrm{e}-\mathrm{f}$

Árvores 5-15 m alt., inermes, caule suberoso, castanho claro. Ramos lisos, pilosos, sulcados, cicatriz estipular evidente. Folhas com pecíolo 5,5-7,6 cm, canaliculado, viloso; raque $16-20 \mathrm{~cm}$, cilíndrica, vilosa; estípulas e estipelas caducas, não observadas; folíolos 2,4-7,9 × 1,4-2,9 $\mathrm{cm}$, concolores, cartáceos, alternos, oblongos, lanceolados ou obovados, base cuneada, ápice agudo; face adaxial esparso-tomentosa, opaca, face abaxial canescente-vilosa; ausência de glândulas ou pontuações translúcidas no limbo; venação broquidródoma; peciólulo $3 \mathrm{~mm}$ compr., tomentoso. Inflorescências paniculadas e axilares; brácteas ausentes; bractéolas ovais, tomentosas. Flores sésseis; cálice campanulado, tomentoso, enegrecido; corola com vexilo 6-7,6 × 5-6,8 $\mathrm{mm}$, alvo, orbicular; asas 5,8 × $2 \mathrm{~mm}$, elípticas; pétalas da carena semelhantes às asas; ovário viloso. Sâmaras 5,5-9 cm compr., oblongas, ápice arredondado, estipe e região seminífera pubérulas, região seminífera basal, às vezes rugosa; sementes 1-1,5 cm compr., estriadas.

Material examinado: Pindorama, Estação Experimental, 15.XI.1938, fl., R. Valentim 41875 (SP).

Material adicional: Alumínio, fl., 3.XII.1998, Tozzi, A.M.G.A. et al. 330 (UEC); Araraquara, 29.XI.1951, fl., Hoehne, W. 14040 (UEC); Brotas, Horto Santa Fé, 14.VIII.12002, fr., Gomes, B.Z. 108 (UEC); Faz. São Vicente, fr., 6.VI.1990, Bernacci, L.C. 25.874 (UEC). 
Machaerium villosum é reconhecido pelos folíolos com face abaxial canescente-vilosa. Ocorre na Bolívia e no Brasil, onde se distribui principalmente nas regiões Sudeste e CentroOeste, em domínios Mata Atlântica e Cerrado, com ocorrências mais esporádicas na região Nordeste, em domínio Caatinga (Tab.1; BFG 2015; speciesLink 2015). Em São Paulo as coletas estão concentradas na região Centro-Leste do estado, em fisionomias de Floresta Estacional Semidecidual e Cerradão (Sartori \& Tozzi 1998; speciesLink 2015). No Noroeste paulista foi encontrada no interior dos fragmentos destas duas fisionomias. A floração foi observada de novembro a fevereiro e a frutificação de junho a agosto.

\section{Myroxylon peruiferum L.f., Suppl. Pl. 233.} 1781.

Fig. $2 \mathrm{~m}-\mathrm{o}$

Árvores 10-15 m alt., inermes, caule rugoso, castanho escuro. Ramos lenticelados, pubérulos. Folhas com pecíolo 1,5-2,5 cm compr., pubérulo; raque 10-12 cm compr., cilíndrica, pubérula, mas sem tricomas ferrugíneos; estípulas e estipelas não observadas; folíolos 2,5-7 × 1,6-2,5 $\mathrm{cm}$, concolores, cartáceos, alternos, obovadolanceolados, base obtusa, ápice acuminado, faces adaxial e abaxial glabras, nítidas, face abaxial com nervura central proeminente; pontuações e traços translúcidos conspícuos em todo o limbo, sem glândulas peltadas na face abaxial; venação camptódroma; peciólulo $2 \mathrm{~mm}$, rugoso, tomentoso. Inflorescências racemosas, terminais e axilares; brácteas lanceoladas, pulverulentas; bractéolas não observadas. Flores com cálice campanulado, esverdeado, pubérulo; corola papilionácea, vexilo $8,4 \times 8 \mathrm{~mm}$, alvo, largo-orbicular, glabro; asas e pétalas da carena indiferenciadas, $7 \times 1 \mathrm{~mm}$ compr., linear oblongas, glabras; estames com filetes livres, fundidos na base; ovário estipitado, glabro, estigma punctiforme. Sâmaras 5,5-9,5 cm compr., douradas, glabras, ala com venação longitudinal, cálice persistente, região seminífera basal, com superfície lisa; sementes $1-1,3 \mathrm{~cm}$ compr., circulares, rugosas, de coloração uniforme, sem arilo.

Material examinado: Matão, Faz. Cambuhy, 27.VII.1995, fr., Rozza, A. 81 (ESA); Paulo de Faria, XI.1994, fl., Souza, V.C. 6272 (UEC e ESA); Penapólis, 14.XI.1980, fl., Pirani, J.R. 11-80 (UEC).

Myroxylon peruiferum pode ser reconhecido pelos pontos e traços translúcidos em toda a lâmina dos folíolos. Ocorre na América Central (México) e América do Sul (Tab.1), no Brasil a espécie distribui-se principalmente nas regiões Sudeste e Centro-Oeste, em domínios de Cerrado e Mata Atlântica, com registros também nas regiões Nordeste e Sul (Paraná) (BFG 2015; speciesLink 2015). Distribui-se principalmente no planalto ocidental do estado de São Paulo e foi encontrada no interior dos fragmentos de Floresta Estacional Semidecidual e Cerradão na região Noroeste. A floração foi observada de junho a setembro e a frutificação em agosto e setembro.

8. Ormosia arborea (Vell.) Harms, Repert. Spec. Nov. Regni Veg. 19: 288. 1924.

Fig. 3g-h

Árvores $10-15 \mathrm{~m}$, inermes, caule suberoso, castanho claro. Ramos cilíndricos, lenticelados, pubérulos. Folhas com pecíolo de $6-9 \mathrm{~cm}$, levemente sulcado, tomentoso; raque $16-17 \mathrm{~cm}$, cilíndrica, com tricomas ferrugíneos; estípulas e estipelas não observadas; folíolos 8,5-20 × 6,5-11,5 cm, concolores, coriáceos, opostos, oblongos, base cordada, ápice retuso; face adaxial glabra, opaca, nervuras proeminentes e nervura marginal espessa, face abaxial esparso-tomentosa na nervura principal; ausência de glândulas peltadas, pontuações translúcidas e traços no limbo; venação camptódroma; peciólulo $5 \mathrm{~mm}$, tomentoso. Inflorescências paniculadas, axilares; brácteas e bractéolas lineares, tomentosas; cálice campanulado, tomentoso-dourado; corola papilionácea, vexilo $1,4 \times 1,1 \mathrm{~cm}$, rosado, suborbicular, glabro; asas 1,2 ×0,4 cm, elípticas; pétalas da carena semelhantes às asas; estames livres; ovário denso tomentoso, tricomas dourados. Legumes 2,5-4 cm compr., orbiculares, estipitados, esparso-tomentosos; sementes 1-1,2 cm compr., orbiculares, bicolores com a testa vermelha e preta, sem arilo.

Material examinado: Amparo, Monte Alegre, IV.1943, fr., Kuhlmann, M. 520(UEC); Macaubal, Distrito de Ida Iolanda, Faz. Pauã, 13.I.2008, fl., Martins, M.V. et al. 155 (BOTU); Matão, Faz. Cambuhy, Mata da Virgínia, 27.VII.1995, fr., Rozza, A. 84 (ESA).

Ormosia arborea é reconhecida por seus folíolos grandes $(8,5-20 \mathrm{~cm}$ compr.), oblongos, com nervuras proeminentes e por suas sementes bicolores. Ocorre em vários países da América do Sul, no Brasil distribui-se nas regiões Nordeste (Bahia), Centro-Oeste (Goiás) e Sudeste (Tab.1), principalmente nos domínios de Mata Atlântica e Cerrado (BFG 2015). No estado de São Paulo há maior densidade de registros de coletas na porção oriental (speciesLink 2015) e na região Noroeste foi encontrada em fisionomia de Floresta Estacional Semidecidual. A floração foi observada de novembro a janeiro e a frutificação em março. 
9. Platypodium elegans Vogel, Linnaea 11: 420422. 1837.

Fig. 3i-j

Árvores 7-20 m alt., inermes, caule suberoso, castanho claro, fissuras longitudinais. Ramos sulcados, tomentosos. Folhas com pecíolo 1,4-2 cm compr., sulcado, tomentoso; raque 11$17 \mathrm{~cm}$ compr., cilíndrica, tomentosa, glabrescente; estípulas deltóides, tomentosas; folíolos 2,5-5,5 × 1-2 cm, concolores, coriáceos, alternos, oblongos, base obtusa, ápice emarginado, mucronado; face adaxial opaca, glabra, face abaxial tomentosa, nervura central proeminente; margem ciliada, ausência de glândulas ou pontuações translúcidas no limbo; venação camptódroma; peciólulo $2 \mathrm{~mm}$ compr., tomentoso. Inflorescências racemosas, terminais e axilares; brácteas lanceoladas, tomentosas; bractéolas não observadas. Flores com cálice turbinado-campanulado, verde, glabro; corola papilionácea, vexilo $2 \times 1,6 \mathrm{~cm}$, oboval-orbicular, amarelo, glabro; alas e pétalas da carena desiguais, asas $1,8 \times 0,7 \mathrm{~cm}$, oblongas, glabras; pétalas da carena $1,4 \times 0,5 \mathrm{~cm}$, obovais, concrescidas dorsalmente, glabras; androceu diadelfo; ovário lateralmente ciliado. Sâmaras 4,5-6,5 cm compr., castanho-claras, glabras, ala com venação transverso-oblíqua, núcleo seminífero apical; sementes 1-1,5 cm compr., oblongo-reniformes, de coloração uniforme, sem arilo.

Material examinado: Macaubal, Distrito de Ida Iolanda, Faz. Pauã, 7.XII.2007, fr., Martins, M.V. 43, 53, 58 (BOTU).

Material adicional: Agudos, Faz. Cia Cervejaria Brahma, 09.X.1997, fl., Christianini, S.R. \& Teixeira Neto, J. 663 (UEC); Bauru, Jardim Botânico, 30.X.1996, fl., Pinheiro, M.H.O. 176 (UEC); Piracicaba, Faz. Pau Alho, 20.X.1984, fl., Catharino, E.L.M. 186 (UEC).

Platypodium elegans pode ser reconhecida pelos folíolos coriáceos, subopostos, oblongos, base obtusa, ápice emarginado e mucronado. Ocorre em vários países da América do Sul (Tab. 1), sendo amplamente distribuída no Brasil desde o Norte e Nordeste até o estado de Santa Catarina, com registros pontuais para a região Amazônica (BFG 2015; speciesLink 2015). No estado de São Paulo é amplamente coletada, com maior densidade de registros no planalto ocidental, em fisionomias de Floresta Estacional Semidecidual e Cerrado (Durigan et al. 2012; speciesLink 2015). No Noroeste paulista foi encontrada no interior e bordas dos fragmentos de Cerradão. A floração foi observada em outubro e a frutificação em dezembro.
10. Pterodon pubescens (Benth.) Benth., J. Linn. Soc., Bot. 4 (Suppl.): 127. $1860 . \quad$ Fig. 3k

Árvores 8-20 m alt., inermes, caule suberoso, castanho. Ramos levemente estriados, os mais velhos ocos internamente, tomentosos. Folhas com pecíolo 2-2,5 cm compr., tomentoso; raque $12-18 \mathrm{~cm}$ compr., cilíndrica, não alada, tomentosa; estípulas e estipelas não observadas; folíolos 2,5-4,5 × 1-1,5 cm, concolores, cartáceos, alternos, elípticos; base obtusa a arredondada, ápice retuso, mucronado, faces adaxial e abaxial esparsamente tomentosas; pontuações translúcidas areoladas no limbo; sem glândulas peltadas na face abaxial; venação camptódroma; peciólulo $2 \mathrm{~mm}$ compr., tomentoso. Inflorescências paniculadas, terminais e axilares; brácteas e bractéolas não observadas. Flores com cálice bilabiado, tomentoso; corola com vexilo $1 \times 1,2 \mathrm{~cm}$, orbicular, róseo, internamente seríceo, mácula central lilás; asas $11 \times 4 \mathrm{~mm}$ compr., obovadas; pétalas da carena $9 \times 3 \mathrm{~mm}$ compr., livres; androceu monadelfo; ovário tomentoso. Criptossâmaras 5-7,5 cm compr., elípticas, muricadas, glabras, plano-compressas, com superfície lisa; sementes ca. $1 \mathrm{~cm}$ compr., circulares, achatadas, de coloração uniforme, sem arilo.

Material examinado: Matão, Faz. Cambuy, fr., 8.II.2008, Martins, M.V. 70 (BOTU); Penapólis, Rodovia 425, 18.IX.1774, fl., Hatschbach, G. 34817 (UEC); Planalto, Faz. Taperão, 10.VIII.2007, fl., Stranghetti, V. et al. 28 (BOTU); Sales, Faz. Águas Claras, 24.VIII.1995, fl., Grecco, M.D.N. 113 (UEC); 28.III.2007, fr., Stranghetti, V. et al. 48 (BOTU); Santo Antônio do Aracanguá, Distrito de Vicentinópolis, Faz. Rancho Alegre, 06.III.2007, fr., Stranghetti, V. et al. 37 (BOTU); 20.II.2008, fr., Martins, M.V. 82 (BOTU); Votuporanga, Faz. Primavera, 16.II.2008, fr., Stranghetti, V. et al. 08 (BOTU).

Pterodon pubescens é reconhecido pelos folíolos elípticos, alternos e pelas flores róseas. Ocorre somente no Brasil, principalmente nas regiões Centro-Oeste e Sudeste, no domínio de Cerrado (Tab.1; BFG 2015; speciesLink 2015). No estado de São Paulo as coletas estão concentradas no planalto ocidental (specieslink 2015) e na região Noroeste foi encontrada em fisionomias de Cerradão, no interior e nas bordas dos fragmentos. A floração foi observada de setembro a outubro e a frutificação em fevereiro e março.

11. Sweetia fruticosa Spreng., Syst. Veg. ed.16, 2: 213. 1825. Fig. 31-m.

Árvores 5-20 m alt., inermes, caule rugoso, internamente amarelado. Ramos lenticelados, estriados, com cicatrizes foliares, glabros, os mais jovens pubescentes. Folhas com pecíolo de 1-2 mm 
compr., canaliculado, glabro a pubescente; raque 6-11 cm compr., semelhante ao pecíolo; estípulas e estipelas não observadas; folíolos 3-6 × 2,5-3 $\mathrm{cm}$, discolores, cartáceos, alternos, oblongos, base obtusa ou arredondada, ápice arredondado a retuso, mucronado; face adaxial e abaxial glabrescente; ausência de glândulas, pontuações translúcidas e traços no limbo; venação craspedódroma; margem ciliada; peciólulo $1 \mathrm{~mm}$, tomentoso. Inflorescências racemosas ou paniculadas, terminais e laterais; brácteas laceoladas, caducas, bractéolas oval-laceolada. Flores com cálice turbinado-campanulado, esverdeado, pubescente; corola papilionácea, vexilo 2,5-3,5 × 5-7 mm, creme-esverdeado, obovado, glabro; alas e pétalas da carena semelhantes entre si, lâmina 3,5-4 × 2-2,5 mm, obovada a espatulada, unha 2-3 mm compr.; androceu pseudomonadelfo; ovário curtamente estipitado, tomentoso; estigma capitado. Sâmaras 6-6,7 cm compr., núcleo seminífero basal; sementes 1-1,3 cm compr., oblongas, coloração uniforme, arilo pouco desenvolvido.

Material examinado: Votuporanga, Faz. Primavera, 15.VIII.2007, fl., Stuchi, L. \& Neto, A.B.A. 687 (BOTU); 16.X.2007, fr., Stuchi, L. \& Neto, A.B.A.1052 (BOTU).

Sweetia fruticosa é reconhecida pelos folíolos discolores, oblongos, ápice arredondado a retuso e mucronado. Ocorre na Bolívia, Paraguai e no Brasil, onde se distribui principalmente na região Sudeste, em domínio de Mata Atlântica (Tab.1), com ocorrências mais esporádicas no Nordeste, Norte e Centro-Oeste e Sul (Paraná) (BFG 2015; speciesLink 2015). Os registros de coletas para a espécie no estado de São Paulo concentram-se no planalto ocidental (specieslink 2015) e foi coletada no interior e nas bordas dos fragmentos de Floresta Estacional Semidecidual e Cerradão na região Noroeste. A floração foi observada de agosto a outubro e a frutificação de outubro a dezembro.

\section{Agradecimentos}

À FAPESP, a bolsa concedida à primeira autora (processo 07/53885-9). Ao Prof. Dr. Rodrigo Schütz Rodrigues, a identificação das espécies do gênero Leptolobium. Aos curadores e funcionários dos herbários BOTU, ESA, IAC, SP, SJRP, SPF e UEC. A Profa. Dra. Neusa Taroda Ranga, o auxílio dado nas coletas através do projeto temático (Fapesp/Biota processo 04/44820-3).

\section{Referências}

Arid, F.M.; Castro, P.R.M. \& Barcha, S.F. 1970. Estudos hidrogeológicos no município de São José do Rio Preto, São Paulo. Boletim da Sociedade Brasileira de Geologia 19: 43-69.

Barcha, S.F. \& Arid, F.M. 1971. Estudo da evapotranspiração na região norte-ocidental do estado de São Paulo. Revista de Ciências da Faculdade de Ciências e Letras 1: 94-122.

Barroso, G.M.; Morim, M.P.; Peixoto, A.L. \& Ichaso, C.L.F. 1999. Frutos e sementes: morfologia aplicada á sistemática de dicotiledôneas. UFV, Viçosa. 426p.

Bentham, G. 1862. Leguminosae-Papilionaceae. Dalbergieae. Machaerium. In: Martius, C.F.P. von \& Eichler, A.G. Flora Brasiliensis. Munchen, Wien, Leipzig. Vol. 15, fasc. 29, tab. 67, 72, 74.

BFG. 2015. Growing knowledge: an overview of Seed Plant diversity in Brazil. Rodriguésia 66: 1085-1113.

Cardoso, D.; Queiroz, L.P.; Pennington, R.T.; Lima, H.C.; Fonty, E.; Wojciechowski, M.F. \& Lavin, M. 2012. Revisiting the phylogeny of papilionoid legumes: new insights from comprehensively sampled earlybranching lineages. American Journal of Botany 99: 1991- 2013.

Doyle, J.J.; Doyle, J.L.; Ballenger, J.A.; Dickson, E.E.; Kajita, T. \& Ohashi, H. 1997. A phylogeny of the chloroplast gene $r b c L$ in the Leguminosae: Taxonomic correlations and insights into the evolution of nodulation. American Journal of Botany 84: 541-554.

Durigan, G.; Baitello, J.B.; Franco, G.A.D.C. \& Siqueira, M.F. 2004. Plantas do Cerrado Paulista: imagens de uma paisagem ameaçada. Páginas \& Letras Editora e Gráfica, São Paulo. 471p.

Durigan, G; Ramos, V.S.; Ivanauskas, N.M. \& Franco, G.A.D.C. 2012. Espécies indicadoras de fitofisionomias na transição Cerrado-Mata Atlântica no estado de São Paulo. Secretaria do Meio Ambiente, São Paulo. 145p.

Fidalgo, O. \& Bononi, V.L.R. 1989. Técnicas de coleta, preservação e herborização de material botânico. Instituto de Botânica, São Paulo. 62p.

Klitgaard, B.B. \& Lavin, M. 2005. Dalbergieae. In: Lewis, G.P.; Schrire, B.D.; Mackinder, B.A. \& Lock, J.M. (eds.). Legumes of the World. Royal Botanical Gardens, Kew. Pp. 307-335.

Kronka, F.J.N.; Nalon, M.A.; Matsukuma, C.K.; Pavão, M.; Ywane, M.S.S. \& Kanashiro, M.M. 2005. Inventário florestal do Estado de São Paulo. Secretária do Meio Ambiente, Instituto Florestal, Imprensa oficial, São Paulo. 200p.

Lewis, G.P.; Schrire, B.D.; Mackinder, B.A. \& Lock, J.M. 2005. Legumes of the world. Royal Botanical Gardens, Kew. 577p.

Lima, H.C. 1989-1990. Tribo Dalbergieae (Leguminosae Papilionoideae) - morfologia dos frutos, sementes e plântulas e sua aplicação na sistemática. Arquivos do Jardim Botânico do Rio de Janeiro 30:1-42. 
Lima, H.C. 1995. Leguminosas da Flora Fluminensis - J.M. da C. Vellozo - lista atualizada das espécies arbóreas. Acta Botanica Brasilica 9:123-146.

LPWG (Legume Phylogeny Working Group). 2013. Legume phylogeny and classification in the $21^{\text {st }}$ century: progress, prospects and lessons for other species-rich clades. Taxon 62: 217-248.

Metzger, J.P. \& Rodrigues, R.R. 2008. Diretrizes para conservação e restauração da biodiversidade no estado de São Paulo: mapas-síntese. In: Rodrigues, R.R. \& Bononi, V.L.R. (eds.). Diretrizes para a conservação e restauração da biodiversidade no estado de São Paulo. Instituto de Botânica, São Paulo. Pp. 132-139.

Necchi Júnior, O. 2012. Fauna e flora de fragmentos florestais remanescentes da região noroeste do estado de São Paulo. Holos, São Paulo. 301p.

Necchi Júnior, O.; Branco, L.H.Z.; Casatti, L.; CastilhoNoll, M.E.M.; Feres, R.J.F.; Ranga, N.T.; Rezende, A.A. \& Rossa-Feres, D.C. 2012. Características da região noroeste do estado de São Paulo e dos fragmentos florestais remanescentes estudados. In: Necchi Júnior, O. (ed.). Fauna e flora de fragmentos florestais remanescentes da região noroeste do estado de São Paulo. Holos, São Paulo. Pp. 4-27.

Pennington, R.T.; Lavin, M.; Ireland, H.; Klitgaard, B.; Preston, J. \& Hu, J.M. 2001. Phylogenetic relationships of basal papilionoid legumes based upon sequences of the chloroplast trnL intron. Systematic Botany 26: 537-556.

Pennington, T. 2003. Monograph of Andira. (Leguminosae- Papilionoideae). Systematic Botany Monographs 64: 1-143.

Pirie, M.D.; Klitgaard, B.B. \& Pennington, T. 2009. Revision and Biogeography of Centrolobium (Leguminosae - Papilionoideae). Systematic Botany 34: 345-359.

Polhill, R.M. \& Raven, P.H. 1981. Advances in Legume Systematics. Royal Botanic Gardens, Kew. 1049p.

Radford, A.E.; Dickison, W.C; Massey, R. \& Bell, C.R. 1974. Vascular plant systematics. Harper \& Row Publishers, Inc., New York. Pp. 1-891.

Rizzini, C.T. 1977. Sistematização terminológica da folha. Rodriguésia 29: 25-103.
Rodrigues, R.S. \& Tozzi, A.M.G.A. 2008. Reinstatement of Leptolobium Vogel (Leguminosae, Papilionoideae, Sophoreae). Taxon 57: 980-984.

Rodrigues, R.S. \& Tozzi, A.M.G.A. 2012. Revisão taxonômica de Leptolobium (Papilionoideae, Leguminosae). Acta Botanica Brasilica 26: 146-164.

Sartori, A.L.B. \& Tozzi, A.M.G.A. 1998. As espécies de Machaerium Pers. (Leguminosae-PapilionoideaeDalbergieae) ocorrentes no estado de São Paulo. Revista Brasileira de Botânica 21: 211-246.

SpeciesLink. 2015. Rede speciesLink e provedores dos dados. Disponível em <http://www.splink.org.br/ index?lang=pt $>$. Acesso em 6 abril 2015.

Taroda, N.T.; Rezende, A.A.; Cavassan, O.; Toniato, T.Z.; Filho, R.C. \& Stranghetti, V. 2012. Caracterização florística de remanescentes de vegetação nativa da região noroeste do estado de São Paulo. In: Necchi Júnior, O. (ed.). Fauna e flora de fragmentos florestais remanescentes da região noroeste do estado de São Paulo. Pp. 97-128.

Tropicos.org. 2015. Missouri Botanical Garden. Disponível em $<$ http://www.tropicos.org $>$. Acesso em 6 abril 2015.

Troppmair, H. 1975. Regiões ecológicas do estado de São Paulo. Biogeografia 10: 1-24.

Vivo, M. 1998. Diversidade de mamíferos do Estado de São Paulo. In: Castro, R.M.C. (ed.). Biodiversidade do Estado de São Paulo: síntese do conhecimento ao final do século XX. FAPESP, São Paulo. Pp. 51-66.

Veloso, H.P.; Rangel Filho, A.L.T. \& Lima J.C.A. 1991. Classificação da vegetação brasileira, adaptada a um sistema universal. IBGE, Rio de Janeiro. 124p.

Wanderley, M.G.L.; Shepherd, G.J.; Martins, S.E.; Estrada, T.E.M.D.; Romanini, R.P.; Koch, I.; Pirani, J.R.; Melhem, T.S.; Harley, A.M.G.; Kinoshita, L.S.; Magenta, M.A.G.; Wagner, H.M.L.; Barros, F.; Lohmann, L.G.; Amaral, M.C.E.; Cordeiro, I.; Aragaki, S.; Bianchini, R.S. \& Esteves, G.L. 2011. Checklist of Spermatophyta of the São Paulo State, Brazil. Biota Neotropica 11: 193-390.

Wojciechowski, M.F.; Lavin, M. \& Sanderson, M.J. 2004. A phylogeny of legumes (Leguminosae) based on analysis of the plastid matK gene resolves many well-supported subclades within the family. American Journal of Botany 91: 1846-1862. 
Lista de coletores

Árbocz, G.F. 664 (1). Bernacci, L.C. 760 (5.2), 769 (6.6), 812 (4), 1633 (6.4), 1651 (6.2), 25.874 (6.8). Catharino, E.L.M. 54 (3), 186 (9). Christianini, S.R. 221 (3). Gomes, B.Z. 108 (6.8). Grecco, M.D.N. 113 (10). Hatschbach, G. 34817 (10). Heringer, E.P. 7341 (1). Hoehne, W. 14040 (6.8). Kirizawa, M. 1348 (5.1). Kuhlmann, M. 520 (8). Lorenzi, H. 28450 (6.6). Martins, M.V. 30 (2), 37 (6.1), 43 (9), 53 (9), 58 (9), 69 (6.4), 70 (10), 72 (3), 73 (6.4), 75 (6.7), 82 (10), 91 (6.5), 95 (6.7), 103 (6.4), 155 (8). Neto, A.B.A.17 (6.6), 348 (5.2), 687 (11), 820 (5.1), 879 (2), 889 (6.3), 899 (6.2), 924 (4), 1052 (11). Pereira-Noronha, M.R. 1603 (2). Pinheiro, M.H.O. 176 (9). Pirani, J.R. 11-80 (7). Rezende, A. 5 (1). Rodrigues, R. S. 1202 (11). Rozza, A. 81 (7), 84 (8). Sartori, A. 29140 (6.5), 30434 (6.7). Sciamarelli, A. 29110 (6.3), 29132 (6.7). Silveira, A.M. 68 (5.1)., 75 (5.2). Souza, V.C. 5683 (6.7),6272 (7). Stranghetti, V. 3 (4), 8 (10), 17 (5.2), 20 (4), 28 (3), 32 (6.7), 37 (10), 41 (6.1), 48 (10), 100 (6.2), 171 (6.6), 237 (6.6). Tamashiro, J.Y. 273 (6.2). Teixeira Neto, J. 663 (9). Tozzi, A.M.G.A. 330 (6.8). Valentim, R. 41875 (6.8). 